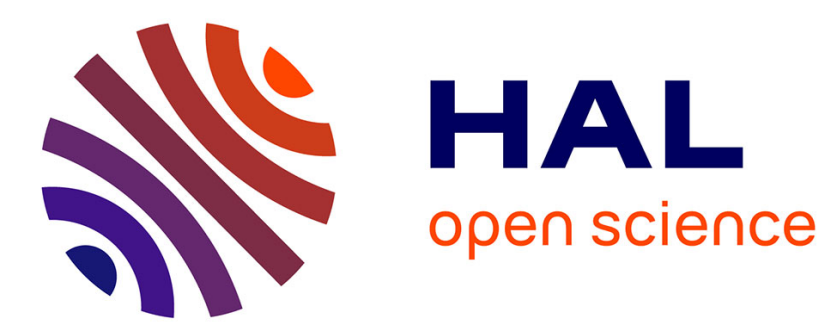

\title{
Silcretes: insights into the occurrences and formation of materials sourced for stone tool making.
}

Médard Thiry, Anthony Milnes

\section{To cite this version:}

Médard Thiry, Anthony Milnes. Silcretes: insights into the occurrences and formation of materials sourced for stone tool making.. Journal of Archaeological Science: Reports, 2016, Special issue, 10.1016/j.jasrep.2016.08.015 . hal-01408425

HAL Id: hal-01408425

https://hal-mines-paristech.archives-ouvertes.fr/hal-01408425

Submitted on 4 Dec 2016

HAL is a multi-disciplinary open access archive for the deposit and dissemination of scientific research documents, whether they are published or not. The documents may come from teaching and research institutions in France or abroad, or from public or private research centers.
L'archive ouverte pluridisciplinaire HAL, est destinée au dépôt et à la diffusion de documents scientifiques de niveau recherche, publiés ou non, émanant des établissements d'enseignement et de recherche français ou étrangers, des laboratoires publics ou privés. 


\section{Silcretes: insights into the occurrences and formation of materials sourced for stone tool making}

Médard Thiry(1) and Anthony Milnes(2)

(1) MINES ParisTech, PSL Research University, Centre de Géosciences, 35 rue St Honoré 77300 Fontainebleau, France.

(2) Department of Earth Sciences, The University of Adelaide, South Australia 5005.

Corresponding author: Médard Thiry 


\section{Abstract}

Silcretes are clearly observed and abundant as components of paleolandscapes on

4 several continents. Mechanisms for the formation of several varieties of silcrete, with specific

5 relationships to paleolandscapes, are described. Each type of silcrete displays particular

6 morphological features in its profile in the paleo-regolith, and these features provide pointers

7 to its origin via mechanisms of absolute or relative accumulation of silica in specific

8 environments relating to groundwater or soil-water hydrology. The characters of silcrete

9 varieties that may have triggered the interest of prehistoric peoples to exploit them for

10 manufacturing stone tools, and which control knappability, include granulometry and the

11 specific nature of silica cements. The successions of silica precipitation and recrystallisation

12 events are clearly evident as a complex of micromorphological features that provide clues to

13 the hydrological environment and its geochemistry at the time or times of silicification.

14 Examples are given of the distribution of different silcrete facies, which could have had

15 differing values for exploitation for stone tool production, in modern-day landscapes in

16 France and Australia.

Highlights

Silcretes occur widely in paleolandscapes in several continents.

What are they and how did they form?

What made silcretes suitable for prehistoric people to form stone tools?

\section{Keywords}

silicification, silcrete, petrography, mineralogy, landscapes, prehistoric tools. 


\section{$361 \quad$ Introduction}

There is a wealth of literature on silcretes in both the geological sciences and the archaeological sciences. In geology it ranges from initial compilations of knowledge like that edited by Langford-Smith (1978) to the comprehensive overview of Nash and Ullyot (2007). In archaeology in Australia the studies described by Holdaway and Fanning (2014) also provide a review of current knowledge and a foundation for future research. The science pertaining to silcretes has actually advanced in parallel in both scientific fields with only limited cross-reference, except perhaps for the work of Webb and his colleagues (Webb and Domanski, 2008). In geology the early work focussed on field observations and relationships, and progressed to petrographic and mineralogical studies, from which hypotheses were generated about origin and palaeoenvironmental conditions. From our geological perspective, some studies of stone tools in archaeological science had a 'primitive' view of silcrete, such as that expressed in Mulvaney \& Kamminga (1999, p 213), but others developed a sophisticated understanding of the rock mechanical properties of silcrete and other siliceous materials (Domanski et al., 1994), and some also used petrographic/micromorphological fabrics and textures (e.g. Summerfield, 1983) to characterise silcrete artefacts and proffer ideas about their provenance. But the connection with step-by-step advances in our understanding of the complex of processes and environmental conditions that have led to the formation of silcretes has not been maintained and the aim of this paper is to at least partly address this situation.

In the first instance, we should be clear about terminology. There are several definitions of the term 'silcrete' but we prefer something along the lines of that proposed by Eggleton (2001), namely;

'Strongly silicified, indurated regolith, generally of low permeability, commonly having a conchoidal fracture with a vitreous lustre. Represents the complete or nearcomplete silicification of regolith by the transformation of precursor silica or silicates and/or the infilling of available voids, including fractures. On a macroscopic scale, some silcretes are dense and massive, but others may be nodular, columnar, blocky, or cellular with boxwork structure. On a microscopic scale, the fabric, mineralogy 
and composition of silcretes may reflect those of the parent material, but also indicate the changes experienced by, as well as the general environments of, silicification. The key component of the definition, from our perspective, is the phrase 'strongly indurated, silicified regolith'. Thus, silica-rich secondary materials including flint, chert, agate, chalcedony, and precious and common opal are not silcretes, though there may be a spatial and temporal association with some forms of silcrete. Sandstone, quartzite and some forms of porcellanite and jasper (as defined, for example, in Gary et al., 1973) that have formed specifically as a result of secondary silicification of the regolith are silcretes, but those resulting from diagenetic alteration or metamorphism are not. Red-brown hardpans (Chartres, 1985; Wright, 1983) are not silcretes because they are generally not 'strongly indurated' by silica.

It is also important to note that the term 'silcrete' is an English word and concept that has no equivalent in the geosciences literature in Latin languages where such material is generally called 'sandstone', 'silicified limestone', 'silicified claystone', and so on. In France, the word 'silcrete' was used for the first time by Parron et al. (1976). As well, 'flint tool' is often used as a generic term in the French literature and could have been formed from silicified limestone or pedogenic silcrete.

The environments of formation and ages of silcretes have been the subject of many investigations over many years, but definitive answers still elude us. Recent work in

84 Australia on the formation and age of precious opal in Great Australian Basin landscapes (Dutkiewicz et al., 2015; Rey, 2013; see also critique by Dickson, 2014 and response by Rey, 2014) did not unravel the genetic and temporal relationship between the widespread formation of opal in voids and fractures in the regolith (within and outside the margins of the Great Australian Basin) and the complex suite of silcrete facies in these regions. Some work on $\mathrm{O} / \mathrm{H}$ isotope composition and trace element chemistry of opal and the siliceous matrix in silcretes (Alexandre et al., 2004; Dutkiewicz et al., 2015; Harwood et al., 2013; Webb and

91 Golding,1998), may provide a future basis for interpreting conditions of formation, though 92 not age.

In this paper we summarise our current thinking on the characteristics, landscape

94 associations, origin and age of silcretes. We also attempt to link petrological and 
95 mineralogical features (which are of specific importance to geologists in generating

96 hypotheses to explain the origin of silcretes) to the potential value of silcretes to prehistoric

97 peoples for the production of stone tools,. However, we recognise that there are substantial

98 fields of knowledge in geoarchaeology and lithic technology that rightly lay claim to the

99 development of an understanding of the associations between prehistoric peoples and the

100 source materials for stone tools.

101 Numerous siliceous materials used for tool making (flint, chert, quartzite, quartz) are

102 bound to geological formations which were buried, then exhumed and exposed fortuitously at

103 the surface in landscapes where they could be accessed, tested and exploited if suitable. On

104 the other hand, silcretes are directly linked to the landscapes in which prehistoric people lived.

105 Those silcretes that frame and armour landsurfaces as duricrusts and lags were highly visible

106 and available for testing and exploitation over wide areas of continents.

107 The most widely known silcrete duricrusts occur now in the desertic landscapes of

108 inland Australia, South Africa, Saharan Africa and the northeast of Brazil. They armour

109 plateaux and mesas dissected by erosion, thus maintaining steep scarps or 'breakaways' cut in

110 vari-coloured soft substrate formations that confer a spectacular aspect to the lands that

111 fascinated prehistoric people and still fascinate tourists. Silcretes are also important regolith

112 features and frame a number of landscapes in temperate regions (for example the

113 superimposed plateaux in the Paris Basin), but are less spectacular because they tend to be

114 covered and hidden by vegetation. During the glacial periods in the Late Cenozoic these

115 northern countries were somewhat bare of vegetation, with contrasting relief.

116 Although there are several forms of silcrete that can be found and recognised on many

117 continents, only some appear to have been suitable for stone tool making. The sites that have

118 generated starting materials for appropriate tools can be readily recognised in the field from

119 the litter of flakes and chips discarded during tool production. Mineralogical and

120 micromorphological properties can explain physical appearance, hardness, lustre and potential

121 durability of silcrete tools and, in some cases, in some regions, point to their provenance.

122 However, archaeologists may not be particularly focussed on sources of silcrete (or other

123 forms of siliceous rocks) that have been opportunistically exploited for the production of 
124 stone tools, but rather seek to recognise specific source materials that have been valued from a

125 technological, aesthetic or symbolic viewpoint and which potentially have been transported

126 long distances. Identifying provenance from this perspective permits them to potentially trace

127 out migration patterns, exchanges, and possibly social behaviour.

\section{Behaviour of silica in regolith environments}

129 In order to explain the internal structures of silcretes, as well as their distribution and

130 location in specific landscape settings, it is important to understand some concepts of silica

131 behaviour in surficial environments.

\subsection{Silica solubility}

$\mathrm{mg} / \mathrm{L} \mathrm{SiO}_{2}$ while the solubility of all other silica phases is significantly lower than this (Fig.

135 1). The most soluble phases in a geochemical system control the precipitation of the less

soluble ones and, in this way, amorphous silica in equilibrium with a solution is able to sustain the crystallisation of every other crystalline silica phase. In turn, cristobalite, tridymite, chalcedony and opal in equilibrium with a solution are able to sustain the crystallisation of quartz (Fig. 1; Garcia-Hernandez, 1981; Gislason et al., 1993; Iler, 1979; Siffert, 1967).

Detailed mineralogical and petrographic studies of silcretes show a consistent and specific sequence of transformation/recrystallisation from more to less soluble phases, 143 namely:

$$
\text { opal } \rightarrow \text { microcrystalline quartz } \rightarrow \text { euhedral quartz }
$$
especially account for the development of complex nodular structures in some forms. The

148 succession of recrystallization is irreversible and ultimately favours the formation of quartz 149 (Thiry and Millot, 1987). 
It should be noted that most natural groundwaters around the world have a silica content between 12 -18 ppm $\mathrm{SiO}_{2}$ (Garrels and Christ, 1965, Swanberg and Morgan, 1978; White et al., 1963) that is roughly in equilibrium with clay minerals. This means that most groundwaters are oversaturated with respect to quartz (solubility 4 - $7 \mathrm{mg} / \mathrm{L}$ ) and are thus potentially able to precipitate quartz when favourable physico-chemical conditions occur. As pointed out by Thiry et al. (2014), solutions with a high silica content favour the formation of crystal nuclei and crystal defects that restrict the growth of crystals and consequently the precipitation of amorphous or low crystallinity silica varieties. However, in dilute solutions, the number of nuclei and impurities remains limited. As a consequence, pure silica crystallites generally form and large quartz crystals can develop or, under less favourable conditions, microcrystalline or fibrous silica varieties are formed.

If silica is present in solution it has to be precipitated in order to generate silicification and ultimately produce a silcrete. Several tracks are possible. It has long been thought that increasing the concentration of the solution by evaporation was the principal triggering factor for silica precipitation in relation to silcrete formation (Auzel and Cailleux, 1949; Millot 1970; Smale, 1973; Storz, 1928). This hypothesis resulted mainly from studies of the widespread silcrete duricrusts in current desertic environments, for example in Australia, South Africa and North Africa. It has now been established that these silcretes do not relate to present day landscapes and climates and are in fact much older. Moreover, it is unlikely that evaporation could be effective in developing meter-thick silicified horizons because it would be much reduced, or cease, as soon as silica cementation commenced. Nevertheless, evaporative processes may assist in concentrating silica in solution in near-surface environments.

In contrast to evaporation, silica solubility decreases exponentially with decreasing temperature. Between 12.5 and $0^{\circ} \mathrm{C}$, the solubility of quartz decreases to half its initial value

175 (Fig. 2). This appears to be a very effective factor in precipitating silica from solution: it had 176 never been envisaged as a mechanism for precipitating silica in the supergene realm until proposed by Thiry et al. (2013, 2015b) but was commonly advocated in hydrothermal

178 environments. 
Increasing the concentrations of salts in solution is another efficient way to decrease

180 silica solubility: the solubility of amorphous silica decreases with increasing salt concentration to saturation (Fig. 3), up to $96 \%$ in the case of $\mathrm{CaCl}_{2}$ and up to $30 \%$ in the case of a $\mathrm{NaCl}$ saturated solution (Marshall, 1980). The mixing of a silica solution with chloriteand/or sulphate-rich brine is certainly a very effective mechanism for inducing the precipitation of silica. The often advocated relation between silicification and warm and dry climates most probably results from the negative relationship between increasing concentrations of evaporite brines and silica solubility.

\subsection{Key geochemical processes in regolith solutions}

As silica in regolith solutions mainly originates from the weathering or alteration of alumino-silicates (such as feldspars and clay minerals) in rocks and sediments, the relative solubilities of Si and $\mathrm{Al}$ must be taken into account. Si and $\mathrm{Al}$ have different domains of stability (Fig. 4).

(1) In acidic environments, $\mathrm{Al}$ and $\mathrm{Si}$ have contradictory behaviours. $\mathrm{Al}$ is more soluble than $\mathrm{Si}$, and so alumino-silicates (clays and feldspars) are destroyed and leached of $\mathrm{Al}$ whereas Si in the silicate frameworks, and silica minerals, remain essentially in situ, most often in the form of opal;

(2) At neutral $\mathrm{pH}, \mathrm{Al}$ and Si behave similarly. $\mathrm{Al}$ and and Si both have a low solubility. Both silicates and silica are relatively stable in this domain;

(3) In alkaline environments $\mathrm{Al}$ and $\mathrm{Si}$ are both highly soluble. Silicates and silica may be altered, but such environments are rare and restricted in continental landscapes (for example alkaline lakes in the east African graben). silicates and clay minerals via dissolution and leaching of $\mathrm{Al}$ and other cations to concentrate

203 silica. However, such acidic environments are not common in regolith environments and 204 require specific conditions to develop. 
Sulfide oxidation is one possibility for the development of acid conditions. It is a consequence of weathering of sulfides present in host rocks, resulting in high concentrations of sulfur in groundwaters, abundant sulfate minerals and an oxidizing environment.

208 Nevertheless, pyrite oxidation will only develop widespread acidity if water flow through

209 these formations is limited. Ultimately, the acidity depends on the degree of oxidation 210 reached:

$$
\begin{aligned}
& \mathrm{FeS}_{2}+7 / 2 \mathrm{O}_{2}+\mathrm{H}_{2} \mathrm{O} \rightarrow \mathrm{Fe}^{++}+2 \mathrm{SO}_{4}^{--}+2 \mathrm{H}^{+} \\
& 2 \mathrm{FeS}_{2}+15 / 2 \mathrm{O}_{2}+7 \mathrm{H}_{2} \mathrm{O} \rightarrow 2\left(\mathrm{Fe}(\mathrm{OH})_{3}+4 \mathrm{SO}_{4}^{--}+8 \mathrm{H}^{+}\right.
\end{aligned}
$$

Ferrolysis is another geochemical process that develops highly acidic environments. It

214 relies on the oxidation of $\mathrm{Fe}^{++}$-bearing solutions by incoming $\mathrm{O}_{2}$, leading to the liberation of $215 \mathrm{H}^{+}$protons (Fig. 5).

$$
\mathrm{Fe}^{++} \rightarrow \mathrm{Fe}^{+++}+2 \mathrm{e}^{-}
$$

218 It has been widely advocated in several soil environments in which clay minerals are

219 degraded by leaching of Al from the silicate framework (Brinkman, 1970). In Western

220 Australia, pyrite oxidation and ferrolysis have been put forward to explain the regional acid saline groundwater systems and hundreds of ephemeral saline lakes characterized by complex acid brines with a $\mathrm{pH}$ as low as 1.4, together with an abundance of alunite, and the large-scale mobilisation of silica and accompanying silcrete formation (Benison and Bowen, 2015;

224 Dickson and Giblin, 2009; Mann, 1983; McArthur et al., 1991).

225 The effectiveness of acidolysis of alumino-silicates (feldspars and clay minerals) with regard 226 to silicification can be appreciated from the mass balance equations:

$$
\begin{aligned}
& 2\left(\mathrm{KAlSi}_{3} \mathrm{O}_{8}\right)+2 \mathrm{H}_{2} \mathrm{O}+2 \mathrm{H}^{+} \rightarrow \mathrm{Si}_{2} \mathrm{Al}_{2} \mathrm{O}_{5}(\mathrm{OH})_{4}+4 \mathrm{SiO}_{2}+2 \mathrm{~K}^{+} \\
& \text {orthoclase } 100 \mathrm{~g} \quad \text { kaolinite } 46 \mathrm{~g} \quad \text { silica } 43 \mathrm{~g} \\
& \mathrm{Si}_{2} \mathrm{Al}_{2} \mathrm{O}_{5}(\mathrm{OH})_{4}+6 \mathrm{H}^{+} \rightarrow 2 \mathrm{Al}^{+++}+2 \mathrm{SiO}_{2}+5 \mathrm{H}_{2} \mathrm{O} \\
& \text { kaolinite } 46 \mathrm{~g} \quad \text { silica } 30 \mathrm{~g}
\end{aligned}
$$

228 The complete acidolysis of orthoclase releases $73 \%$ by weight of silica: this could remain in

229 situ to contribute to the formation of a silcrete (relative accumulation of silica) or be released 
230 in solution to infiltrate, and initiate silicification of, specific zones or horizons in the regolith

231 (absolute accumulation of silica).

234 of silica.

235 Relative accumulation of silica occurs primarily as the result of the dissolution and

236 leaching of alumino-silicate minerals, specifically silicates such as feldspars and clays (Rayot

237 et al., 1992; Thiry et al., 2006). The process requires an acidic environment that is aggressive

238 towards these minerals and generates the loss of non-Si elements, resulting in an in situ

239 concentration of silica. There appears to be no significant transport of Si within the system

240 but only limited local reorganization and adjustment. However, leaching of cations other than

241 silica generates a significant loss of material leading to the disruption and collapse of primary

242 fabrics and structures.

Absolute accumulation occurs through importation of silica to the system. The silica may replace pre-existing minerals or simply fill voids, fractures and intergranular pores. The silica has to originate from somewhere else and has to be brought into the horizon that undergoes silicification. With regard to the relatively low solubility of silica in surficial waters and the relatively large volume of silica needed to infill pore spaces to effect

248 silicification, this kind of silica accumulation requires large volumes of water to flow through

249 the horizon. This is only conceivable in groundwater outflow zones (springs, seeps) and

250 implies landscape incision in order to intersect groundwater tables. Primary geological

251 structures in the host horizon are characteristically preserved.

\section{$2523 \quad$ Varieties of silcrete}

Silcretes take a wide variety of forms and detailed investigations of these forms from

254 the field scale to that available via scanning microscopy provide clues to their origin. Aspects

255 such as field distribution, geomorphological patterns and relationships to current and former

256 landscapes, petrology and mineralogical-geochemical characteristics have all to be 
considered. We group silcretes into two classes: groundwater silcretes that form mainly as a result of the absolute silica accumulation of silica in regolith environments; and pedogenic silcretes that reflect the relative accumulation of silica, as well as a complex of dissolution,

260 eluviation and illuviation processes typical of soil environments. Nash and Ullyott (2007) have suggested a sub-classification of 'non-pedogenic' silcretes into ‘drainage-line' and 'pan/lacustrine' types', but these forms can be encompassed satisfactorily within groundwater silcretes from our perspective. Of particular interest in the landscape context is that volume is mostly conserved during the formation of groundwater silcretes, whereas volume is substantially lost during the formation of pedogenic silcretes, some of which can be metres thick in profile.

\subsection{Groundwater silcretes}

The main characteristics of groundwater silcretes are their disposition as a series of superposed silicified lenses in the regolith and the preservation of primary host-rock structures (stratification, bioturbation, fossils). There are two main varieties: those that occur in sands and develop into massive quartzitic facies by infilling and cementation of pore spaces between detrital quartz grains; and those that are created by epigenetic replacement of limestones, claystones and even gypsum horizons, and therefore have more irregular and discontinuous shapes.

\subsubsection{Quartzitic types}

These are typically formed in sands by cementation of the detrital quartz grains via syntaxial quartz overgrowths, or other forms of silica, precipitated in pore spaces. The initial condition is always a porous sediment. Quartzitic silcretes generally form well-confined flatlying pans within unconsolidated or poorly cemented sands. Those in the Fontainebleau Sand

280 have been studied in detail and are good examples.

282 levels within the Fontainebleau Sand formation (Thiry et al., 1988; Thiry et al., 2013; Thiry et 283 al., 2015a). The silcrete lenses typically crop out on the edges of plateaux or in valley margins but pinch out rapidly under the limestone-capped plateaux, as shown by drill holes 
and observations in sand quarries (Fig. 6). This strong link between silcrete distribution and present-day geomorphology suggest that these silcretes developed relatively recently in and near outcrop zones of the Fontainebleau Sand. Sand calcite contained in the silcretes date the silicification to Pleistocene glacial periods (Thiry et. al., 2013).

Geomorphological and geological constraints suggest that silicification occurred in groundwater outflow zones (springs, seeps) during landscape incision (Thiry et al., 1988; Fig. 7). The key process sequence is:

- precipitation of silica in horizons of the Fontainebleau Sand in a zone of groundwater outflow; and

- resumption of erosion leading to lowering of the groundwater table and the formation of a new silcrete pan via groundwater outflow during a subsequent period of landscape silcrete has come from groundwater contained within the formation. Its silica content ranges from 10 - 15 ppm, which is about three times the saturation value of quartz (4 - 6 ppm) at surface temperatures and pressures.

The correlation of silica cementation with glacial periods, as determined by age dating of contained calcite crystals, suggests that silica precipitation occurred by cooling of groundwaters along discharge pathways towards outflow zones in frozen soils in the valleys. Hydraulic and geochemical mass balance calculations, based on the silica content of water in an average current-day spring, indicate that cementation could potentially take place over about 2000 years. This is a short geological time span and totally changes previous interpretations of the time-scale for the formation of some silcretes.

311 Pleistocene in North America (Ludwig and Paces, 2002; McCoy, 2011), and such an origin

312 may apply to other occurrences, like those within white sandstone formations in Germany 
313 (Götze and Walther, 1995) and in the Czech Republic (Mikulas, 2002), Greece (Skarpelis,

314 2006), southern France (Parron et al., 1976) and Spain (Bustillo and Bustillo, 2000; Parcerisa

315 et al., 2001), for which the origins have not yet been considered in detail. Quartzitic silcrete

316 pans may also develop in very different environments, including those that have not

317 apparently experienced cold climates. For example, in Australia (Thiry and Milnes, 1991)

318 and southern Africa (Summerfield, 1983; Nash et al., 1998), quartzitic silcretes may have

319 formed in groundwater environments in dry paleoclimates where silica precipitation could be

320 attributed to a mixing of fresh and saline waters. Nevertheless, all examples relate to

321 groundwater outflows in incised landscapes and for which silica has been imported in order to

322 provision precipitation and cementation.

\subsubsection{Silicified limestone/calcrete types}

Many lacustrine limestone formations contain irregular silicified masses and have long been described from dry regions such as the Kalahari Desert, North Africa and Australia, as well as in more humid countries like France, Spain and the USA (Alimen and Deicha, 1959;

327 Banks, 1970; Daley, 1989; Kaiser, 1928; Nash et al., 2004; Thiry and Ben Brahim, 1997).

328 The silica was generally thought to have precipitated during dry periods at the time of

329 limestone deposition in confined environments. However, petrographic observations and

330 geochemical data have generated new ideas about the formation of these silcretes.

The extensive Tertiary lacustrine limestones of the Paris Basin form superimposed plateaux that constitute the dominant geomorphologic features. Typical examples are the Brie and Beauce plateaux. Almost all of these limestones contain zones of silicification (Cayeux,

334 1929). Their size varies from millimetre-sized dots to siliceous bodies several tens of meters

335 long. The silicified facies have an irregular distribution (Fig. 8): locally, they can form over

$33610 \%$ of a quarry cliff-face, but are absent a short distance away. On the regional scale they

337 average about $5 \%$ of the volume of the lacustrine limestone in the southern Paris Basin.

Two types of silicification coexist: deposits of quartz and chalcedony in voids; and epigenetic replacement of the limestone matrix by microcrystalline quartz, with preservation of the primary sedimentary structures. Thin sections show a systematic link between 
341 silicification and zones of high porosity, either preserved or partly infilled by silica deposits

342 (Thiry and Ribet, 1999).

343 Because the silicified limestones are pure, without any sandy or clayey layers, silica

344 had to be imported from elsewhere. And as the limestones have never been deeply buried, the

345 importation of silica can only have been via substantial near-surface groundwater flows,

346 which could explain the relationship between porosity and the intensity and extent of the

347 silicification. This is a very different mechanism of silica accumulation from that represented

348 by flints and cherts. In this case, silicification occurs during burial diagenesis whereby there

349 is epigenetic replacement of limestone by silica originating in microfossils in specific

350 sedimentary layers, without the formation of any voids.

Substantial groundwater outflows are only possible after uplift and incision of the

limestone formation. In the Paris Basin, such conditions were only fulfilled during the

Pliocene and the Quaternary periods and, therefore, the silicification had to occur relatively quickly (Thiry and Ribet, 1999). Similar groundwater silicification of limestone has already been described in present day hydrologic systems in inland Australia (Arakel et al., 1989; Benbow, 1993), southern Africa (Nash et al., 2004) and Spain (Armenteros et al., 1995). As for quartzitic silcretes, silica precipitation was probably triggered by different geochemical mechanisms (water cooling or water mixing, or others), under very different climatic and environmental conditions. However, the resulting petrographic fabrics are similar: dissolution of calcite making space for precipitation of silica, which may lead to very contrasted fabrics.

Weathering of Paris Basin silicified lacustrine limestone during Pliocene-Quaternary times produced cavernous silicifications called "meulières" which delineate plateau surfaces in the southern Paris Basin (Beauce Plateaux; Thiry, 1999). The meulières show a large variety of facies from massive to highly porous ‘cellular' facies and can be weathered and desilicified into friable blocks, even breaking down into a rough sand-like material.

\subsubsection{Porcellaniteljasper types}

Fine grained silcretes, obviously resulting from silicification of primary clay-rich materials, form specific facies, generally of glassy appearance, and often resembling flint or chert except for their colour which is generally due to iron-oxide inclusions. Such materials 
370 have been described in several geological contexts (Boule, 1888; Millot et al., 1959, Valleron, 371 1981).

Such silicifications are widespread in inland Australia and are commonly associated with bleached and weathered profiles in rocks and sediments ranging in age from Precambrian to Quaternary (Simon-Coinçon et al., 1996). The profiles are up to 60m deep. Their main characteristics are white or pastel colour and low bulk density, together with the occurrence of alunite, iron oxide mottling, extensive bioturbation by termite burrows that penetrate to great depth, and ubiquitous gypsum that has crystallised in fractures and voids (Thiry et al., 1995; Thiry et al., 2006). The bleached material is mainly formed of quartz, large booklet-like kaolinite and opal A, with alunite and gypsum in pods and veins (Fig. 9). In some localities the burrows and their fillings, as well as the enclosing saprolite, have been silicified. K/Ar dating of alunite in these profiles indicates a Miocene age for the bleaching and weathering, varying from about 16 - $18 \mathrm{Ma}$ in the Coober Pedy opal field to about 8 - 12 Ma in the Andamooka opal field (Bird et al., 1990).

These profiles have resulted from alteration under acidic conditions in a saline groundwater environment nearly saturated in gypsum (Thiry et al., 1995). The bleaching was related to the lowering of the groundwater table. Arid conditions at the time restricted water flow and allowed an acidic environment to develop to leach original alumino-silicates, retain Si (as amorphous silica and quartz), but not completely lose some of the most soluble elements like $\mathrm{K}, \mathrm{Ca}, \mathrm{SO}_{4}$ and $\mathrm{Al}$ from the system that form nodules and veins of alunite and gypsum in places. Elevated concentrations of anatase (Fig. 9) could indicate that Ti released from primary alumino-silicates has also been retained.

Horizontally disposed lenses or pods of porcellanite or jasper subsequently developed in the bleached saprolite (Fig. 9). Primary sedimentary structures and fabrics, as well as some

394 fabrics relating to weathering and bleaching, in particular iron-mottling, have been retained 395 within these silica-indurated horizons. The superposition of several silica-indurated layers 396 relates to still-stand positions of paleo-water tables which rose significantly after the widespread bleaching, thus reflecting a return to more humid climatic conditions. 
Low concentrations of clays in the porcellanite and jasper horizons compared with the

399 host regolith (Fig. 9) points to acidic environments that probably developed via ferrolysis and

400 generated silica via relative accumulation. However, micromorphological examination shows

401 that the silicified horizons are cemented by various silica phases. The silica cements were

402 precipitated from water inflow, either by infiltration through the upper part of the profile, or

403 by lateral flow of groundwater containing silica through the profile. The silica was probably

404 derived from dissolution of silica (opal-A, quartz) and silicates (clays) in the bleached profile.

405 The formation of these groundwater silcretes required a consistent hydraulic flow regime that

406 was probably related to down cutting of the landscape (Simon-Coinçon et al., 1996). Silica

407 precipitation points to mixing of fresh silica-charged water with sulphate-rich groundwater,

408 thus lowering silica solubility.

\subsection{Pedogenic silcretes}

Pedogenic silcretes developed near the landsurface, within soil environments, and

411 display typical soil structures (geopetal features) related to infiltration of downward

412 percolating water (such as differentiated horizons, eluviation and illuviation structures).

413 Details of this silcrete type come mainly from Eocene occurrences in the Paris Basin (Thiry,

414 1981). Specific characteristics and mechanisms of formation are also derived from

415 observations of similar materials in Australia (Milnes and Thiry, 1992; Simon-Coinçon et al.,

416 1996; Thiry and Milnes, 1991) and Central America (Elsass et al., 2000).

In the southern part of the Paris Basin, silicified pans and lenses cap Eocene detrital

418 kaolinitic deposits. These are very hard, tightly cemented quartzitic silcretes that break up into

419 variably sized blocks, with puffy, tear-like shapes, coated with deposits ('cappings') of

420 yellow-white opaline silica that mask the internal structures. Typically, the silcretes have a

421 columnar structure with characteristic laminated cappings on the columns (Fig 10). They are

422 about $2 \mathrm{~m}$ thick and display several distinct horizons with systematic micromorphological and

423 mineralogical structures (Thiry, 1981).

424 A lower granular horizon consists of a sandy claystone with millimetric- to

425 centimetric-sized granules of microcrystalline quartz and opal. TEM and electron diffraction 
studies of the clay matrix show that hexagonal-shaped kaolinites have corrosion embayments and are coated and welded together by a silica gel.

An overlying columnar horizon has a matrix composed of detrital quartz grains with

429 irregular overgrowth apophyses which grade into titania-enriched microcrystalline quartz.

430 Ghosts of granules are easily recognizable within the matrix. Illuviation cutans of opal have

431 developed in fractures. The youngest laminae, at the top of the illuviation structures, always

432 consist of opal with a low titania content. The initial laminae, at the base of the illuviation

433 structures, commonly have a nodular structure and are formed of microcrystalline quartz with

434 a higher titania content. This sequence indicates a progressive recrystallisation of the opal.

435 Recrystallisation is accompanied by loss of silica, which induces the destruction of the 436 primary structures and relative accumulation of titania.

A more massive horizon, with complex nodular and pseudo-breccia fabric, is found at

438 the top of the profile. It is devoid of opal and the microcrystalline quartz matrix has partly

439 dissolved. Titania has accumulated in rims around the nodules. Euhedral quartz has developed

440 in the voids and some quartz grains show overgrowths.

441 Pedogenic silcretes occur widely in central and southern Australia and have been

442 described in detail from the opal fields (for example Fig. 9, near-surface horizon) and the 443 region around Alice Springs (Milnes and Thiry, 1992; Milnes and Twidale, 1983; Simon444 Coinçon et al., 1996; Thiry and Milnes, 1991). Their morphology is typically that described 445 by Thiry and colleagues from around the Paris Basin (Barrois, 1878; Thiry, 1981), with wide 446 variations in the appearance of the columnar facies being evident in different localities. As 447 well, pedogenic silcretes occur widely in north-western Europe, in Belgium on the Ardennes 448 (Gosselet, 1888), in Germany on the Slate Mountains massifs (Lange; 1912; Teichmüller, 449 1958) and in the London Basin (Kerr, 1955, Summerfield, 1980). They armour South African 450 and Botswanan landscapes where Summerfield (1983) described highly variable textures and 451 fabrics classifying the main petrographic characteristics as 'grain-supported fabric' (quartzitic 452 silcrete with quartz overgrowths), 'floating fabric' (silicified clayey matrix with coarse 453 detrital grains), and 'glaebular fabric' (containing illuviation structures typical of soils). 
In terms of the origin of pedogenic silcretes, opal initially formed in the granular horizon and at the base of joints in the columnar horizon where water circulation was slow and stagnation had occurred. Higher in the profile, the microcrystalline matrix dissolved. Well-crystallised quartz crystals formed at the top of the profile. Profiles clearly show a migration of silica from top to bottom and the inheritance, in the uppermost horizons, of micromorphological features which initially developed in the lowermost horizons. This inheritance demonstrates that silicification progressively 'eats' into the landscape like a weathering front. The greatest amount of silica comes from dissolution at the top of the profile followed, from top to bottom, by a sequence of precipitation and re-dissolution events.

The close link between leached and confined environments does not imply a strict synchronism of degradation and construction. The two systems work in an alternating fashion, whereas periods of loss (leaching) and accumulation (precipitation) follow one another more or less sequentially.

Initially silica originated from the degradation of clay minerals at the base of the profile, possibly in a highly acidic environment triggered by ferrolysis. The mineral sequence, from top to base of the profile, results from a progressive concentration of silica and other cations in infiltrating and downward-moving solutions. The silica content of the solution could be concentrated by 2 to 4 times through evaporation during dry periods and silica precipitation favoured by increasing cation concentration.

\section{$4 \quad$ Characteristics of silcretes of relevance to tool making}

Silcretes show numerous variations in their morphology and their spatial arrangement but also vary in their composition and internal texture. A classification of silcretes based on micromorphological fabrics by Summerfield (1983) has been used widely in archaeological studies to identify different types of silcrete artefacts. Indeed, each silcrete type may display various types of cement and porosity, with sometimes decimetric scale variation, but this does

479 not relate to their convenience or value for tool making. Particular facies, with interesting 480 mechanical properties or appearance could exist within larger masses and may have been specifically sought and used. 
Various crystallization fabrics have developed according to the nature of the host

483 formation and/or the chemistry of the silica-bearing solutions. The nature of silica cements

484 and the geometrical relations between crystals are the predominant determinants of the

485 mechanical properties of silcretes. Substantial research in this field has been undertaken in

486 Australia from an archaeological perspective (e.g. Domanski et al., 1994; Webb and

487 Domanski, 2008). These investigations have determined that tool-making depends on two

488 main characteristics: the hardness of the material to form cutting and wear-resistant tools, and

489 the capacity to produce a regularly curved conchoidal fracture that permits the detachment of

490 long and thin knappings.

491 It is not within our capability to examine the knappability of silcrete types, nor to

492 make reference to the variety of silcrete facies used by prehistoric peoples to make stone

493 tools. Much of the formal understanding of the mechanical properties of silcretes and other

494 rocks from which stone tools were made, and the influence on these properties by heat

495 treatment, which is believed to have been commonly practiced, has been comprehensively

496 detailed (e.g. Domanski et al., 1994; Domanski and Webb, 1992; Domanski and Webb, 2007;

497 Webb and Domanski, 2008). Our objective is to illustrate how some petrographic fabrics of

498 silcretes, which we use to help unravel their origin and environment of formation, may effect

499 knappability.

500 Broadly speaking, silcretes that have the finest grain size and the least porosity display

501 the best developed conchoidal, vitreous fracture surfaces. From a petrological and

502 mineralogical perspective, the finest grain size will occur in those silcretes formed

503 predominantly of opal, which can be a complex of hydrated, poorly crystallised silica phases

504 (opal-A, opal-CT) and is consequently comparatively soft (Mohs hardness 5-6). In those

505 silcretes in which the matrix is dominantly microcrystalline quartz, of which there are several

506 types ranging from granular to fibrous varieties, the Mohs hardness is that of quartz (7) and,

507 depending on the microporosity, fracture surfaces can be glassy in appearance. As the

508 abundance of detrital framework quartz grains increases, for example in pedogenic silcretes

509 and some quartzitic groundwater silcretes, the smoothness and lustre of fracture surfaces is 
controlled essentially by the bonding between framework grains and matrix silica, and can be

511 influenced by the abundance of other constituents including micro-cryptocrystalline anatase.

\section{1 'Sandstone' cementation}

In clean sands, without a clay matrix, such as the Fontainebleau Sand, precipitated

514 silica builds on the crystal structure of each detrital quartz grain, leading to the development

515 of euhedral crystal faces. On continued precipitation, crystal faces come into contact, and

516 finally form triple point junctions at the site where the pore space has closed (Fig. 11). The

517 overgrown and expanded quartz grains are not welded together, but only meshed in a compact

518 way. This provides cohesion and hardness to a quartzitic silcrete formed in this manner.

519 When broken by hammering or knapping, the fractures can cross cut quartz grains but tends to

520 follow the euhedral crystal faces of the overgrowth quartz that make contact between the

521 grains. This results in a rough fracture surface of sugary appearance. Such fractures are not

522 suitable for making thin blades or sharp cutting edges.

523 Cementation of quartz grains may also be achieved as the result of precipitation of

524 silica in pore spaces between the grains (Fig. 11), either in the form of opal (quasi-amorphous

525 silica) which may have later re-crystallized into chalcedonite, or direct precipitation of

526 chalcedonite sheaves. These silica deposits give rise to stronger cementation than quartz

527 overgrowths and this is linked to the bonding between the detrital quartz grains and the silica

528 precipitates and the complex intercrystallite connections in the pore spaces. Accordingly, the

529 fracture in these silcretes tends to be 'clean' and cuts across the detrital quartz grains. When

530 the detrital quartz grains are relatively small and the silica deposits occupy the main part of

531 the porosity, the fractures may even be conchoidal and lustrous. This is most likely when the

532 pore fillings are of microcrystalline quartz.

\subsection{Silicified limestones}

In silicified limestones the carbonate matrix has been replaced by silica. The substitution is mainly epigenetic, which means that primary limestone structures such as

536 nodules and fossils are replaced by silica and conserved. For this to occur, there can be no 
537 dissolution of the carbonate before replacement: substitution occurs step by step along a clear

538 'alteration front' between existing limestone and incoming silica. This replacement implies

539 concomitant leaching of the carbonate and precipitation of silica. Voids are necessary for

540 water circulation and their shape and size determines the density and 'quality' of the

541 silicification.

542 If the voids have the form of micro-karst, which develops as the silica precipitates

543 (Fig. 12), the resulting silcrete could be very dense, as translucent as flint and with a lustrous

544 conchoidal fracture. On the other hand, when the dissolution features are larger, or when

545 carbonate residues remain as impurities in the silicified zones, then the resulting silcrete has a

546 dull aspect and a rough surface and is much less convenient for tool making.

547 Quartz is generally the main silica mineral and occurs as both epigenetic replacement

548 and also euhedral overgrowths in pores. Some of the fine microcrystalline matrix may result

549 from recrystallization of primary opal. Chalcedonite and laminated opal deposits occur in

550 pores in some sites (Fig. 12). The presence of opal and poorly crystallized forms of silica

551 may be favourable for heating transformation of these silcretes which is sometimes observed

552 naturally in outcrop in Australia.

$553 \quad 4.3$ Porcellanites and jaspers

These materials are of fine grain size and are formed mainly of various petrographic varieties of opal. The matrix resulting from the alteration of the primary material is generally formed of milky opal made opaque by impurities and microporosity. The most compact samples, with a glossy break, also contain translucent concretionary opal that cements the pores within the matrix (Fig. 13) and this may, in some samples, make up more than $50 \%$ of the silcrete. Concretions generally show successive sequences of silica precipitation in which there are alternations of thin laminae and thicker botryoidal layers of clear and brown opal.

561 The opal has been deposited uniformly around the voids, indicating a saturated groundwater 562 environment.

563 Crystalline varieties of silica occur also in these silcretes. They have formed by 564 recrystallisation of opal, either preferentially in some concretions as part of the sequence of 
565 deposition, or as in response to some form of alteration front (Fig. 13). The initial opal

566 deposits have often recrystallized to chalcedonite while the brown opal of the matrix has

567 transformed to microcrystalline quartz.

568 The opal deposits generally strengthen the silcrete and generate lustrous conchoidal

569 fractures when knapped. However, when exposed at the landsurface in Australia,

570 porcellanites can exhibit extensive crazing as a result of volume changes on dehydration of

571 the opal phases.

\subsection{Pedogenic silcretes}

Pedogenic silcretes are highly variable in form and facies which results from the

574 diversity of the silicified parent materials (colluvium, clayey sand, clay silt, granite, bedrock

575 sandstone) and the position of the sample within the profile (columnar or nodular facies).

576 Adding to the variability is the mineralogical composition which records successive

577 recrystallization stages within the profile.

578 The most abundant and the most typical facies are tightly indurated by a dominantly

579 microcrystalline quartz cement and have a conchoidal and lustrous fracture. Opal is mostly

580 limited to less indurated facies at the base of the profiles and to specific micromorphological

581 features within the profile that are always limited spatially and in volume.

582 The density and homogeneity of the microcrystalline quartz matrix can result in a 583 material that is well-suited for knapping. The amoeboid microcrystals of quartz in net-like 584 arrangement (Fig. 14) confers a structure and texture that mimics the characteristics of some

585 flints. Silicified silty claystones that contain fine-grained detrital quartz and a substantial

586 microcrystalline matrix can be knapped particularly well.

587 A principal criterion for recognising pedogenic silcretes is the omnipresence of

588 illuviation structures, particularly cutans at the base of voids and cappings over quartz grains

589 and granules. These are very clearly distinguished because they are outlined by opaque

590 microcrystalline titania (Fig. 14). As well, the common shard-like remnants of detrital quartz 
591 grains point to significant dissolution and concomitant 'repacking' of the framework prior to

592 cementation, leading to a net volume loss in the profile as a whole.

\section{Silcrete in landscapes}

There are two aspects relating to silcretes in a landscape context. In the first case,

595 from the geological perspective, the occurrence and form of silcretes, particularly where

596 profile observations can be made, provides the basis for interpreting the environment of

597 formation of the silcrete. Macroscopic form and structure indicate the relative simplicity or

598 complexity of the processes of formation, point to single stage or overprinting characteristics,

599 and indicate conservation of volume and preservation of fabric and structure (groundwater

600 environments) or dissolution and loss of material with consequent and complex disruption in

601 the profile and, presumably, of the landsurface (pedogenic silcretes).

602 In the second case, within each category of silcrete, and even within a given category

603 in a particular location, the macroscopic and microscopic fabric and structure can vary

604 considerably. This is less so in the case of groundwater silcretes than for pedogenic silcretes.

605 Only particular forms of silcrete appear to have had value for the production of stone tools.

606 Mulvaney and Kamminga (1999), for example, point to the possibility that some forms of

607 silcrete could have been selected for tool production for aesthetic or symbolic reasons,

608 including their colour, which can be variable. Holdaway et al. (2008) and others (Doelman et

609 al., 2001) make the distinction between 'outcrop silcrete' and the extensive lag gravels

610 ('gibber plains'), the latter (also called 'stony deserts') resulting from downwasting of the

611 ancient pedogenic silcrete-capped landsurfaces and associated groundwater silcrete-

612 impregnated regolith over large areas of inland Australia (Fujioka et al., 2005). They point

613 out that artefacts were made from each source, but that outcrops were more difficult for

614 Aboriginal people to exploit for tools than gibber lags because of the greater supply of hand-

615 sized cobbles in the latter.

616 Thus, if we want to explore the use of silcrete as a raw material for stone tools, for

617 example to map the routes of particular source materials and thus delimit territories and

618 exchanges between prehistoric groups of peoples, it is necessary to locate these materials in 
the landscapes of the studied areas and the territories of the people exploiting them. In this context, inventories of the locations of specific silicified formations, and their petrographic characteristics, would be required for both local and regional areas. This research would utilise an understanding of silcretes and silcrete facies in a landscape context because prehistoric peoples had deeply-embedded connections with landscapes and their features.

\subsection{Inland Australia}

As is well known, pedogenic silcretes in Australia armour glacis (pediments) on the edges of plateaux and around paleorelief (Milnes and Thiry, 1992; Milnes and Twidale, 1983; Simon-Coinçon et al., 1996; Thiry et al., 1991; Twidale and Milnes, 1983a, b). At the edges of scarps extending from the Arcoona Plateau in South Australia, for example, silicification is restricted to thin 'skins', with a very high titania content, coating joint fractures and other surfaces on quartzite bedrock (Hutton et al., 1972; Fig. 15). On the proximal part of the Beda pediment, just downslope from the scarp-foot zone of the plateau, silcrete is more extensive and almost only formed of thick cappings (5 to $20 \mathrm{~cm}$ thick) on bouldery quartzite scree, whereas in the distal areas of the pediment silcrete forms a regular horizon with columnar structure within the pediment. Thicker silcretes occur in the transition zones between the glacis and the lowland plains, where water discharge is still important but flow rates have slowed.

The facies with thick cappings on scree boulders is symptomatic of the complexity that can face any archaeological search for the source of silcrete tools. These cappings are of very hard silcrete with a convex lustrous break and have been exploited for tools as shown by

640 the litter of flakes and chips surrounding the outcrops. They may have been sought

641 specifically because of certain characteristics. However, this particular facies is of very

642 limited extent and locating it as a source of particular stone tools would only be possible after 643 a very detailed inventory of a wide area.

644 In localities along the scarp of the Stuart Range, near Coober Pedy, in northern South 645 Australia, a comprehensive analysis of the geomorphology of the region (Simon-Coinçon et 646 al., 1996) delineated the age relationships between the different weathering and silicification 
647 features (Fig. 16). The pedogenic silcrete armours a wide paleopediment (tableland) dipping

648 from the Stuart Range near Lake Eyre to the Eucla Basin in the southwest, a distance of about

$649500 \mathrm{~km}$. The weathered and bleached profiles are younger. Groundwater silcretes,

650 specifically quartzite and diverse porcellanite horizons, post-date the bleaching. Downcutting

651 and erosion ultimately generated the breakaway scarps now characteristic of the region.

652 The large variety of silicified materials in the Stuart Range landscapes are shown

653 schematically in more detail in Figure 16. Pedogenic silcretes may be locally buried beneath

654 younger deposits (clayey sediments and red-brown hardpans) but are omnipresent at or near

655 the surface of the widespread remnants of the Stuart Range tableland and available in

656 numerous outcrops and extensive lag gravels ('gibber plains', 'stony deserts'). The facies vary

657 according to the parent material affected by the silicification (coarse- or fine-grained;

658 abundant matrix material, or not, between the residual detrital grains). Illuviation structures

659 enriched in titania are symptomatic of these facies. To find any specific characteristics of a

660 particular facies in a particular location would seem to be difficult. On the other hand,

661 groundwater silcretes (quartzite, porcellanite and jasper of variegated colour) are available in

662 outcrops and lag gravels along the creeklines that leading down to Lake Eyre. They have

663 more distinctive characters and a detailed inventory may provide tracers of specific materials.

664 About 700km north of Coober Pedy and the Stuart Range, in the Todd River Plain

665 near Alice Springs in central Australia, similar paleogeographic relationships occur. Here, in

666 the scarp foot zone of a formerly extensive early Cenozoic pediment developed over the

667 Amadeus Basin, mesas and buttes capped by the massive and impressive columnar facies of a

668 pedogenic silcrete overlie a bleached and weathered regolith containing groundwater silcretes

669 (Milnes and Thiry, 1992; Milnes and Twidale, 1983). In distal parts of the pediment there

670 are plateau remnants armoured by thick groundwater silcretes and adjacent areas of silicified

671 limestones (Fig. 17).

672 Here, also, the silicified facies are extremely varied and the associated bleached

673 profiles are rich in white kaolinic clays and Fe oxides of variegated colours. Small mesas of

674 fine quartzitic sandstone have been intensively quarried for tool-making. The steep scree-

675 slopes around the hills and parts of the plateau surface are in places buried by thick deposits 
676 of discarded flakes and chips. The clear evidence of significant (and possibly long-term)

677 exploitation provides the basis for characterising the source silcrete in detail and exploring the 678 distribution of stone tools made from it.

679 However, the vast region, maybe 1 million $\mathrm{km}^{2}$, stretching from central South

680 Australia to the central parts of the Northern Territory, essentially marking the western part of

681 the Lake Eyre Basin (see Alley, 1998; Fujioka et al., 2005) has innumerable outcrops and

682 derivative lag gravels of pedogenic and various groundwater silcretes, all of which could be

683 exploited by Aboriginal people. Thus, there would be a significant challenge in progressively

684 building an inventory of these materials sufficient to assist archaeological investigations in

685 attributing artefacts to sources.

686 The nature and abundance of source material for tool-making has been noted from the

687 first archaeological works in inland Australia by Aiston (1928), who stated “.. it was so easy

688 to make a tool that directly one failed to work satisfactorily it was discarded and a fresh tool 689 made, a supply of stone material always being kept handy for this purpose...”. The experience

690 of Australian archaeologists comes both from stone tools excavated from archaeological sites

691 and from ethnographic records of the experience of old Aboriginal people. Both types of

692 study concluded that Aboriginal people were highly opportunistic in their use of source stone

693 and took mostly varieties of local raw materials, including chert, chalcedony, jasper, silcrete

694 ('grey billy' in the vernacular), quartzite, basalt, silicified wood as well as other igneous and

695 metamorphic rocks (Cane, 1992; Flenniken and White, 1985). Nevertheless, small but

696 significant amounts of non-local materials have been found dispersed over long distances and

697 are thought to relate to migrations of prehistoric Aboriginal people during periods of drought

698 (Gould and Saggers, 1985; Holdaway and Fanning, 2014; Mulvaney and Kamminga, 1999).

$699 \quad 5.2$ Paris Basin

700 The Paris Basin is bounded by Jurassic marine limestone overlain by thick chalk 701 deposits with alternating continental and marine Tertiary deposits in the centre. The most 702 remarkable feature of the Tertiary sequence is the interbedding of sandstone formations with 703 limestones and marls. The present-day morphology of the Paris Basin, namely superimposed 
704 limestone plateaux, results from major uplift during the Pliocene and Quaternary which

705 initiated downcutting and erosion of the Tertiary formations (Fig. 18). Silicified materials

706 occur in almost all formations.

707 Pedogenic silcretes extend from the peripheral basement in the Central Massif and

708 Britanny to the centre of the basin (Fig. 18). They developed along a paleosurface shaped by

709 clastic discharge during the lower Eocene (Blanc-Valleron and Thiry, 1997). Silicification

710 affects palaeoweathering profiles of clay-with-flint above Jurassic limestones and Cretaceous

711 chalks, old alluvium to form thick puddingstones, and sandy clays that become the

712 predominant silicified material at the border of the basin. The thickest silicified profiles (more

713 than 15m thick) are found in grabens and channels that formed the lowlands (Thiry and

714 Simon-Coinçon, 1996).

715 Groundwater silcretes developed in almost every Tertiary formation in the centre of

716 the basin. Tightly cemented quartzite lenses occur in all sandy formations and silicified zones

717 are present in every lacustrine and marine limestone formation (Thiry, 1999). Even the

718 weathered materials topping the limestone plateaux contain large silicified features.

719 Groundwater silcretes also developed in sandy and conglomeratic regolith materials topping

720 the Mesozoic sequences bordering the basin. Recent groundwater cementation has been

721 superimposed on former pedogenic silcrete profiles on the outer borders of the basin. It is

722 likely that 5 to $10 \%$ of the outcropping formations in the basin are silicified, and this

723 represents a considerable mass of easily accessible silcrete for potential exploitation.

724 Added to this inventory as well are Jurassic cherts and Cretaceous flints that occur all

725 over the Paris Basin. They are in situ in the Mesozoic formations or occur in extensive areas

726 covered by paleoweathering profiles of clay-with-flint and reworked into thick alluvial

727 deposits within valleys that dissect the plateaux. These Jurassic cherts and Cretaceous flints

728 generally account for the main component of lithic source material. Their identification was

729 essentially based on micropaleontological determinations and was consequently limited in

730 terms of pointing to source areas (Masson, 1981; Valensi, 1953).

731 Due to the predominance of cherts and flints, less interest has been applied to the 732 recognition of various silcrete facies. Nevertheless, some investigations, in particular in the 
733 Paris Basin, identified several kinds of silcretes used for making tools. Fine-grained

734 quartzitic silcretes from Fontainebleau have been recognized in flakes (Robin, 1974), used for

735 polished axes (Bostyn et al., 2012), and even to made into thin leaf-shaped Solutrean points

736 (Sacchi et al., 1996). These silcretes correspond to the uppermost facies, directly below the

737 limestone cover, and are of glassy appearance due to the presence of microquartz together

738 with quartz overgrowths forming the cement. Bartonian silicified lacustrine limestone has

739 also been recognized (by means of its fossil content) in polished axes that are thought to have

740 been dispersed up to $250 \mathrm{~km}$ (Bostyn et al., 2012). Elsewhere, similar Bartonian silicified

741 lacustrine limestone has been found together with artefacts made from meulière (weathered

742 silicified limestone), silicified Lutetian marine limestone and quartzitic silcretes (Augereau,

743 2008; Lanchon et al., 2008; Mauger, 1985; Surmely, 2009).

744 Recent studies in and around the margins of the Massif Central, taking into account

745 the petrography of cherts, flints and silcretes, including changes in response to their colluvial

746 and alluvial reworking, made it possible to refine source areas (Fernandes, 2012; Surmely et

747 al., 2008). It has to be stressed that it is in basement areas (Massif Central and Bretagne)

748 where the siliceous materials are scarce that the sourcing studies were the more skilful and the

749 most successful. Detailed studies of flint and chert cortices from the Massif Central made it

750 possible to consider natural dispersion of the primary materials and consequently to determine

751 more precisely the source areas (Fernandes, 2012). Silcrete deposits exist also in these

752 basement areas, although scattered and variable in facies. Detailed studies have been able to

753 track the dissemination of these materials within the massif as well as those imported from the

754 peripheral basins (Aubry, 1991; Célérier, 1990; Dabard et al., 2012; Delvigne, 2012; Surmely

755 et al., 2008; Wragg-Sykes, 2014).

\section{$\begin{array}{lll}756 & 6 & \text { Identifying provenance }\end{array}$}

There are certainly specific macroscopic criteria that could be used to help identify

758 sources of silcrete tools, but most of the time these investigations are ambiguous. Colour,

759 grain size and distribution, and the character and aspects of the break, are generally not

760 specific. The morphologies of silcretes are often typical at the outcrop scale, but not at the

761 artefact scale. 
Micromorphological and petrographical features of silcretes are more reliable criteria

763 of origin and potential provenance. However, identification of provenance from these

764 features requires a comprehensive inventory of actual local and regional source materials, a

765 sound geological knowledge of these occurrences, and an accompanying database of

766 micromorphological and petrographical observations of representative samples. This is

767 conceivable on a local scale but is much more difficult to manage on the regional scale of

768 societal exchanges. Geochemical criteria, particularly the concentrations of indicator trace

769 elements, may be helpful. Dutkiewicz et al. (2015) have analysed major and (particularly)

770 trace elements in both opal and host rocks in Australia in order to identify the possible origin

771 of the silica. This approach could potentially be extended to silcretes although, in pedogenic

772 silcretes, the complex of silica forms and associations with microcrystalline anatase and other

773 phases, and the multiplicity of silcrete facies, even on the scale of an outcrop, would pose a

774 significant challenge. Moreover, Holdaway and Fanning (2014) and others have pointed out

775 the complexities presented by the suite of stone artefacts in archaeological sites wherein there

776 are local and foreign sourced materials representing an interplay of unknowable activities.

777 Finally, questions of the extent of post-discard alteration and degradation of

778 archaeological materials has to be addressed. Exoscopic studies of the surfaces of stone tools,

779 which are often altered in various ways by patina evolution, can provide few critical data

780 (Fernandes, 2012; Thiry et al., 2014).

The difficulty for archaeological studies is to precisely characterize the many varieties of silica-rich source rocks for stone tools. In the past, only stratigraphic characters and fossils

783 have been used to determine the provenance of tool materials (Mauger, 1984). This was of

784 limited use because the stratigraphic levels are relatively widespread. More detailed, multi-

785 criteria identification is necessary and essential for understanding trade and acquisition 786 strategies involving stone tools.

787 Progress is possible by taking into account precise micromorphological characteristics

788 that will potentially point to source sites. However, this approach requires an insightful

789 inventory and petrographic data led by archaeological studies (Fernandes, 2012). Inventories

790 of this type are yet not available. Even existing geologic and geomorphological maps do not 
make reference to the specific characters of silcretes, silcrete profiles, or micromorphological

792 features of particular facies, that could be key to these types of investigations. The

793 foundations of such inventories exist, but a new generation of linked archaeological and

794 geological research would be a next step.

\section{$\begin{array}{lll}795 & 7 & \text { Summary }\end{array}$}

Several forms of silcrete are recognised in remnants of paleolandscapes in Europe,

797 Africa and Australia dating from the Mesozoic to the present day. Their chemical,

798 mineralogical and physical (microstructural) composition accounts for their persistence and

799 for the major influence of some silcretes in defining the unique morphology of landforms. All

800 silcretes, of which there are 4 - 6 main types, formed as a result of the introduction and

801 precipitation of silica, for example via groundwaters, or the mobilisation and precipitation of

802 silica from pre-existing minerals via alteration and the leaching of other elements, for

803 example in acidic environments. Each is characterised by a variety of silica polymorphs,

804 including quartz, various forms of microcrystalline and cryptocrystalline quartz, and various

805 forms of opal (opal-CT, opal-A), in particular micromorphological arrangements. The main

806 categories of silcrete originated in pedogenic or groundwater environments.

807 Other than their mode of occurrence and morphological appearance, it is the

808 microstructural composition of silcretes, dictated by mineralogical and micromorphological

809 features that derive from their origin, that provides the basis for understanding their physical

810 and mechanical properties (which relates to the attractiveness of some forms to prehistoric

811 peoples for the making of effective tools). However, it is well recognised that there may have

812 been other practical and even aesthetic or symbolic dimensions to such choices.

813 Investigations of the provenance of stone tools, other than in a local area, will be challenged

814 by a need for regional inventories of silcrete facies.

\section{References}

817 Aiston, G., 1928, Chipped stone tools of the Aboriginal tribes east and north-east of Lake

818 Eyre, South Australia. Papers and Proceedings of the Royal Society of Tasmania, p. 123819131. 
820 Alexandre, A., Meunier, J-D., Llorens, E., Hill, S.M., Savin, S.M., 2004, Methodological improvements for investigating silcrete formation: petrography, FT-IR and oxygen isotope ratio of silcrete quartz cement, Lake Eyre Basin (Australia). Chemical Geology, 211, p. 261-274.

Alimen H., Deicha G., 1959, Observations pétrographiques sur les meulières pliocènes. Bull. Soc. Géol. Fr., (6), 8, p. 77-90.

Alley N.F., 1998, Cainozoic stratigraphy, palaeoenvironments and geological evolution of the Lake Eyre Basin. Palaeogeography, Palaeoclimatology, Palaeoecology, 144, p. 239-263. Arakel, A.V., Jacobson, G., Salehi, M., Hill, C.M., 1989, Silicification of calcrete in paleodrainage basins of the Australian arid zone. Austr. Jour. Earth Sciences, 36, p. 7389.

Armenteros, I., Bustillo, M.A., Blanco, J.A., 1995, Pedogenic and groundwater processes in a closed Miocene basin (northern Spain). Sedimentary Geology, 99, p. 17-36.

Aubry, T., 1991, L’exploitation des ressources en matières premières lithiques dans les gisements solutréens et badegouliens du bassin versant de la Creuse (France). PhD Thesis, University Bordeaux-1, 327 p.

Augereau, A., 2008, Territoires techniques et économiques au Néolithique dans le Bassin parisien. Archéopages, INRAP, 21, p. 16-21.

Auzel, M., Cailleux, A., 1949, Silicifications nord-sahariennes. Bull. Soc. Géol. Fr., (5), 19, p. 553-559.

Banks, N.G., 1970, Nature and origin of early and late cherts in the Leadville Limestone, Colorado. Geol. Soc. Amer. Bull., 81, p. 3033-3048.

Barrois, C., 1878, Sur l'étendue du système tertiaire inférieur dans les Ardennes et sur l'argile à silex. Ann. Soc. géol. Nord, 4, p. 340-376.

Benbow, M.C., 1993, Tallaringa, South Australia. Explanatory Notes 1:250 000 Geological Series - Sheet SH 53-5. Department of Mines and Energy South Australia, 40 p.

Benison, K., Bowen, B.B., 2015, The evolution of end-member continental waters: The origin of acidity in southern Western Australia. GSA Today, 25/6, p. 4-10.

Bethke, C.M., 2002, The geochemist's workbench release 4.0: a user's guide to Rxn, Act2, Tact, React, and Gtplot. University of Illinois, Urbana, IL.

Bird, M.I., Chivas, A.R., McDougall, I., 1990. An isotopic study of surficial alunite in Australia, 2. Potassium argon geochronology. Chem. Geol. (Isot. Geosci. Sect.) 80, p. 133-145. 
853 Blanc-Valleron, M.M., Thiry, M., 1997, Clay minerals, paleoweathering, paleolandscapes and climatic sequences: The Paleogene continental deposits in France. in: Soils and Sediments: Mineralogy and Geochemistry, H. Paquet, N. Clauer, (eds.), Springer, p. 223-247.

Bostyn, F., Couderc, J., Giligny, F., Lethrosne, H., Le Maux, N., Lo Carmine, A., Riquier, C., 2012, La production de haches dans l'Ouest de l'île-de-France (Yvelines, Val-d’Oise). Approche typo-technologique et spatiale. In: Produire des haches au Néolithique, de la matière première à l'abandon, de Labriffe P. A. and Thirault E. (eds), Actes de la table

Boule, M., 1888, Le bassin tertiaire de Malzieu (Lozère). Bull. Soc. géol. Fr., ser. 3, 13, p. 341-345.

Brinkman, R. (1970). Ferrolysis, a hydromorphic soil forming process. Geoderma, 3/3, p. 199-206.

Bustillo, M.A., Bustillo, M., 2000, Miocene silcretes in argillaceous playa deposits, Madrid Basin, Spain: petrological and geochemical features. Sedimentology, 47, p. 1023-1037.

Cane, S., 1992, Aboriginal perceptions of their stone tool technology: a case study from the Western Desert, Australia. Australian Archaeology, 35, p. 11-31.

Cayeux, L., 1929, Les roches sédimentaires de la France. Roches siliceuses. Mém. servir expl. Carte Géol. détaillée de la France, 774 p.

Célérier, G., Duchadeau-Kervazo, C., Gourdon-Platel, N., 1990, Les dalles silicoferrugineuses du Bassin de la Dronne : origine, caractérisation et utilisation préhistorique. In: Actes du colloque international sur le silex, Cahiers du Quaternaire, 17, p 111-117.

Chartres, C.J., 1985, A preliminary investigation of hardpan horizons in north-west New South Wales. Aust. J. Soil Res., 23, p. 325-337.

Dabard, M.-P., Marchand, G., Monnier, J.-L., Querré., G. , 2012, Roches sédimentaires siliceuses du Massif Armoricain. Rrépartition géographique, minéralogique et économie au cours de la Préhistoire. In: Roches et Sociétés de la Préhistoire. Entre massifs cristallins et bassins sédimentaires, Marchand G. and Querré G., (eds), Presses Universitaires de rennes, p. 123-137.

Daley, B., 1989, Silica pseudomorphs from the Bembridge limestone (upper Eocene) of the Isle of Wight, southern England and their palaeoclimatic significance. Palaeogeography, Palaeoclimatology, Palaeoecology, 69, p. 233-240. 
Delvigne, V., 2012, Petroarchaeological study of the unit F2 of the Rond du Barry cave 304.

Dickson, B.L., 2014, Discussion on 'Opalisation of the Great Artesian Basin (central Australia): an Australian story with a Martian twist’ by P.F. Rey (AJES 60, 291-314). Aust. J. Earth Sciences, 60, p. 831-833.

Dickson, B.L., Giblin, A. M., 2009, Features of acid-saline systems of Southern Australia. Applied Geochemistry, 24, p. 297-302.

Doelman, T., Webb, J., Domanski, M., 2001, Source to discard: patterns of raw material procurement and use in Sturt National Park, northwestern New South Wales. Archaeology Oceania, 36, p. 15-33.

Domanski, M., Webb, J.A., 1992, Effect of heat treatment on siliceous rocks used in prehistoric lithic technology. J. Archaeological Science, 19, p. 601-614.

Domanski, M., Webb, J.A., 2007, A review of heat treatment research. Lithic Technology, 32, p. 153-194.

Domanski, M., Webb, J.A., Boland, J., 1994, Mechanical properties of stone artefact materials and the effect of heat treatment. Archaeometry, 36, p. 177-208.

Dutkiewicz, A., Landgrebe, T.C.W., Rey, P.F., 2015, Origin of silica and fingerprinting of Australian sedimentary opals. Gondwana Research, 27, p. 786-795.

Eggleton, R.A., (ed), 2001, Regolith Glossary: surficial geology, soils and landscapes.

$$
\text { Cooperative Research Centre for Landscape Evolution and Mineral Exploration, }
$$
Canberra, A.C.T., 144 p.

Elsass, F., Dubroeucq, D., Thiry, M., 2000, Diagenesis of silica minerals from clay minerals in volcanic soils of Mexico. Clay Minerals, 35/3, p. 477-489.

Fernandes, P., 2012, Itinéraires et transformations du silex : une pétroarchéologie refondée, application au Paléolithique moyen. Thèse Université Bordeaux I, ED Sciences et Environnement, Spécialité Préhistoire, Vol. 1 Texte et figures 452 p, Vol. 2 Annexes 164 p. 19 juin 2012.

Flenniken, J.J., White, J.P., 1985, Australian flaked stone tools: a technological perspective. Records of the Australian Museum, 36/3, p. 131-151.

Fujioka T., Chappell J., Honda, M., Yatsevich I., Fifield K., Fabel D., 2005, Global cooling initiated stony deserts in central Australia 2-4Ma, dated by cosmogenic ${ }^{21} \mathrm{Ne}-{ }^{10} \mathrm{Be}$. Geology, 33, p. 993-996. 
Garcia-Hernandez, J.E., 1981. Interprétation cinétique de la géochimie d'altération de la silice à basse température $\left(25^{\circ} \mathrm{C}\right)$. INRA, Versailles, $213 \mathrm{p}$.

Garrels, R.M., Christ, C.L., 1965, Solutions, Minerals and Equilibria. Harper and Row, NewYork, $450 \mathrm{p}$.

Gary, M., McAfee, R., Wolf, C.L., (eds) 1973. Glossary of Geology. American Geological Institute, Washington, DC, 805 p.

Gislason, S.R., Heaney, P.J., Oelkers, E.H., Schott, J., 1997, Kinetic and thermodynamic properties of moganite, a novel silica polymorph. Geochimica et Cosmochimica Acta, 61/6, p. 1193-1204.

Gosselet, J., 1888, L’Ardenne. Mém. serv. exp. carte géol. Fr., Paris, 888 p.

Götze, J., Walther, H., 1995, An integrated mineralogical and geochemical study on a silicified Miocene quartz sand. Zbl. Geol. Paläont., Teil 1, 1/2, p. 119-129.

Gould, R.A., Saggers, S., 1985, Lithic procurement in Central Australia: a closer look at Binford's idea of embeddedness in archaeology. American Antiquity, p. 117-136.

Harwood, J., Aplin, A.C., Fialips, C.I., Iliffe, J.E., Kozdon, R., Ushikubo, T., Valley, J.W., 2013, Quartz cementation history of sandstones revealed by high-resolution SIMS oxygen isotope analysis. J. Sedim. Res., 83, p. 522-530.

Holdaway, S., Shiner, J., Fanning, P., Douglass, M., 2008, Assemblage formation as a result of raw material acquisition in western New South Wales, Australia. Lithic Technology, 33, p. 73-85.

Holdaway, S., Fanning, P., 2014, Geoarchaeology of Aboriginal Landscapes in Semi-Arid Australia. CSIRO Publishing, 195 p.

Hutton, J.T., Twidale, C.R., Milnes, A.R., Rosser, H., 1972, Composition and genesis of silcretes and silcrete skins from the Beda valley, southern Arcoona Plateau, South Australia. J. Geol. Soc. Australia, 19, p. 31-39.

Iler, R.K., 1979. The chemistry of silica. Solubility, Polymerisation, Colloid and Surface Properties and Biochemistry. John Wiley and Sons, New York, 866 p.

Kaiser, E., 1928, Die chemische Gesteinsaufbereitung in der Südlichen Namib. in: Die Diamantenwüste Sudwestafrikas, Dietrich Reiner, Berlin, Ch. 26, p. 283-316.

Kerr, M.H., 1955, On the occurence of silcretes in southern England. Proc. Leeds Phil. Soc.,

951 Lanchon, Y., Bostyn, F., Hachem, L., Maigrot, Y., Martial, E., Boitard-Bidault, E., 2008, Le 
953

954

955

956

957

958

959

960

961

962

963

964

965

966

967

968

969

970

971

972

973

974

975

976

977

978

979

980

981

982

983

984

« les Pétreaux » (Seine-et-Marne). Revue archéologique d'Île-de-France, tome 1, p. 4394.

Lange, O., 1912, Ueber Silikatsteine für Martinofen. Stahl und Eisen, 32, 42, p. 1731.

Langford-Smith, T., (ed), 1978. Silcrete in Australia. University of New England, Armidale, 314 p.

Ludwig, K.R., Paces, J.B., 2002, Uranium-series dating of pedogenic silica and carbonate, Crater Flat, Nevada. Geochimica and Cosmochimica Acta, 66(3), p. 487-506.

McArthur, J.M., Turner, J.V., Lyons, W.B., Osborn, A.O., Thirlwall, M.F., 1991, Hydrochemistry on the Yilgarn Block, Western Australia: ferrolysis and mineralisation in acidic brines. Geochemica et Cosmochemica Acta, 55, p. 1273-1288.

McCoy, Z. L. , 2011, The Distribution and Origin of Silcrete in the Ogallala Formation, Garza County, Texas. Doctoral dissertation, Texas Tech University, 148 p.

Mann, A.W., 1983, Hydrogeochemistry and weathering on the Yilgarn Block, Western Australia - ferrolysis and heavy metals in continental brines. Geochim. Cosmochim. Acta, 47, p. 181-190.

Marshall, W.L., 1980, Amorphous silica solubilities III : activity coefficient relations and predictions of solubility behavior in salt solutions, $0-350^{\circ} \mathrm{C}$. Geochim. Cosmochim. Acta, 44, p. 925-931.

Masson, A., 1981, Pétroarchéologie des roches siliceuses. Intérêt en Préhistoire. Thèse Université Claude Bernard Lyon I, 111 p.

Mauger, M., 1984, L'apport des microfossiles dans l'identification des silex. Exemple du Magdalénien de l'Ile-de-France. Bulletin de la Société préhistorique française, 81/7, p. 216-220.

Mikulas, R., 2002, Ichnofabric of Oligocene silcretes at Kryry and Detan, Western Bohemia, Czech Republic. Journal of the Czech Geological Survey, 47/3, p. 157-160.

Millot, G., 1970, Geology of clays : weathering, sedimentology, geochemistry. SpringerVerlag, New-York, 429 p.

Millot, G., Radier, H., Muller-Feuga, R., Defossez, M., Wey, R., 1959, Sur la géochimie de la silice et les silicifications sahariennes. Bull. Serv. Carte Géol. Als. Lor., 12, 2, p. 3-15

Milnes, A.R., Thiry, M., 1992, Silcretes. In Martini I.P. and Chesworth W. (eds), "Weathering, Soils and Paleosols". Developments in Earth Surface Processes 2, Ch. 14, p. 349-377. Elsevier: Amsterdam. 
Milnes, A.R., Twidale, C.R., 1983, An overview of silicification in Cainozoic landscapes of arid central and southern Australia. Aust. J. Soil Res., 21, p. 387-410.

Mulvaney, J., Kamminga, J., 1999, Prehistory of Australia. Allen \& Unwin: St Leonards,

$$
\text { NSW, } 480 \text { p. }
$$

Nash, D.J., Mclaren, S.J., Webb, J.A., 2004, Petrology, geochemistry and environmental significance of silcrete calcrete intergrade duricrusts at Kang Pan and Tswaane, central Kalahari, Botswana. Earth Surface Processes and Landforms, 29(12), p. 1559-1586.

Nash, D.J., Shaw, P.A., Ullyott, S., 1998, Drainage-line silcretes of the Middle Kalahari: an analogue for Cenozoic sarsen trains. Proccedings of the Geologists' Association, 109, p. 241-254.

Nash, D.J., Ullyott, J.S., 2007, Silcrete. In: Nash, D.J., McLaren, S.J., (eds), Geochemical sediments and landscapes. Blackwell, Oxford, p. 95-143.

Parcerisa, D., Thiry, M., Gomez-Gras, D., Calvet, C., 2001, Proposition d'un modèle de silicification superficielle des grès néogènes de Montjuïc, Barcelone (Espagne) : paragenèses minérales, environnements géochimiques et circulation des fluides. Bull. Soc. géol. France, 172/6, p. 751-764.

Parkhurst, D.L., Appelo, C.A.J., 1999, User's guide to PHREEQC (Version 2): A computer program for speciation, batch-reaction, one-dimensional transport, and inverse geochemical calculations. Water-Resources Investigations Report 99-4259, US

$$
\text { Geological Survey, } 312 \text { p. }
$$

Parron, C., Nahon, D., Fritz B., Paquet, H., Millot G., 1976, Désilicification et quartzification par altération des grès albiens du Gard. Modèles géochimiques de la genèse des dalles quartzitiques et silcrètes. Sci. Géol., Bull., 29, p. 273-284.

Rayot, V., Self, P., Thiry, M., 1992, Transition of clay minerals to opal-CT during groundwater silicification. In: Schmitt, J-M., Gall, Q., (eds), Mineralogical and geochemical records of paleoweathering. ENSMP Mem. Sc. de la Terre 18, p. 47-49.

Rey, P.F., 2013, Opalisation of the Great Artesian Basin (central Australia): an Australian story with a Martian twist. Aust. J. Earth Sciences, 60, p. 291-314.

Rey, P.F., 2014, Remarks on the age of precious opal in central Australia: reply to comment by Bruce Dickson. Aust. J. Earth Sciences, 60, p. 835-837.

Robin, A.-M., 1974, Une industrie moustérienne en forêt de Fontainebleau. Bull. Soc. Préhist. Fr., 71/3, p. 67-69. 
Sacchi, C., Schmider, B., Chantret, F., Roblin-Jouve, A., Bouysonne ,M., Drapier, S., 1996, Le gisement solutréen de Saint-Sulpice-de-Favières (Essone). Bull. Soc. Préhistorique fr., 93/4, p. 502-527.

Siffert, B., 1967. Some reactions of silica in solution: formation of clay. Translation of: the U.S. Department of Agriculture and the National Science Foundation, Washington, D.C., 100 p.

Simon-Coinçon, R., Milnes, A.R., Thiry, M., Wright, M.J., 1996, Evolution of landscapes in northern South Australia in relation to the distribution and formation of silcretes. J. geol. Soc. London 153, p. 467-480.

Skarpelis, N., 2006, Lateritization processes of ultramafic rocks in Cretaceous times: the fossil weathering crusts of mainland Greece. Journal of Geochemical Exploration, 88(1), p. 325-328.

Smale, D., 1973, Silcretes and associated silica diagenesis in southern Africa and Australia. J. Sedim. Petrol., 43, p. 1077-1089.

Storz, M., 1928, Die sekundären authigenen Kieselsöuren in ihrer petrogenetischgeologischen Bedeutung. Monogr. z. Geologie und Pal., Ser. II, Heft 4, 481 p.

Summerfield, M.A., 1980, The sarsens of Southern England: their paleoenvironmental interpretation with reference to other silcretes. In: The shaping of Southern England, (Jones E.K.C. ed.), Inst. Br. Geogr. Spec. Publ., Academic Press, London, 11, p.71-100. Summerfield, M.A., 1983, Petrography and diagenesis of silcrete from the Kalahari Basin and Cape coastal zone, Southern Africa. J. Sedim. Petrol., 53, p. 895-909.

Surmely, F., 2009, Recherches sur les haches polies des départements de la Seine-et-Marne et du Loiret. Bulletin de la Société préhistorique française, 106(3), p. 593-596.

Surmely, F., Boudon, P., Briot, D., Pin, C., 2008, La diffusion des silex crétacés dans le centre du Massif central durant la préhistoire (Paléolithique, Mésolithique, Néolithique). Contribution à l'étude de la circulation des matières premières lithiques sur de longues distances. PALEO. Revue d'archéologie préhistorique, 20, p. 115-144.

Swanberg, C.A., Morgan, P., 1978, The linear relation between temperatures based on the silica content of groundwater and regional heat flow: a new heat flow map of the United States. Pure and Applied Geophysics, 117/1-2, p. 227-241

Teichmüller, R., 1958, Die Niederreihnische Braunkohlenformation. Stand der Untersuchungen un offene Fragen. Fortschr. Geol. Reihnland und Westf., 2, p. 721-750. 
1050

1051

1052

1053

1054

1055

1056

1057

1058

1059

1060

1061

1062

1063

1064

1065

1066

1067

1068

1069

1070

1071

1072

1073

1074

1075

1076

1077

1078

1079

1080

1081

1082

1083

Thiry, M., 1981, Sédimentation continentale et altérations associées: calcitisations, ferruginisations et silicifications. Les Argiles Plastiques du Sparnacien du Bassin de Paris. Sci. Géol. Mém., 64, 173 p.

Thiry, M., 1999, Diversity of continental silicification features: examples from the Cenozoic deposits in the Paris Basin and neighbouring basement. In Palaeoweathering, palaeosurfaces and related continental deposits (Thiry M. and Simon-Coinçon R., eds), Spec. Publ. Intern. Ass. Sediment., 27, p. 87-128.

Thiry, M., Ben Brahim, M., 1997, Silicifications de nappe dans les formations carbonatées tertiaires du piedmont atlasique (Hamada du Guir, Maroc). Geodinamica Acta, 10, p. 1229.

Thiry, M., Bertrand Ayrault, M., Grisoni, J.-C., 1988, Ground-water silicification and leaching in sands: Example of the Fontainebleau Sand (Oligocene) in the Paris Basin.Geol. Soc. Am., Bull., 100, p. 1283-1290.

Thiry, M., Fernandes, P., Milnes, A., Raynal, J. P., 2014, Driving forces for the weathering and alteration of silica in the regolith: Implications for studies of prehistoric flint tools. Earth-Science Reviews, 136, p. 141-154

Thiry, M., Millot, G., 1987, Mineralogical forms of silica and their sequence of formation in silcretes. J. sedim. Petrol., 57/2, p. 343-352.

Thiry, M., Millot, R., Innocent, C., Franke, C., 2015, The Fontainebleau Sandstone: bleaching, silicification and calcite precipitation under periglacial conditions. Rapport de Recherche, RS150901MTHI, Centre de Geosciences, Ecole des Mines de Paris, Fontainebleau, France, 26 p.

Thiry, M. Milnes, A.R., 1991, Pedogenic and groundwater silcretes at Stuart Creek opal field, South Australia. J. Sedim. Petrol., 61, p. 111-127.;

Thiry, M., Milnes, A.R., Ben Brahim, M., 2015, Pleistocene cold climate groundwater silicification, Jbel Ghassoul region, Missour Basin, Morocco. Journal of the Geological Society, 172/2, p. 125-137.

Thiry, M., Milnes, A.R., Rayot, V., Simon-Coinçon, R., 2006, Interpretation of palaeoweathering features and successive silicifications in the Tertiary regolith of Inland Australia. Journal of the Geological Society, 163, p. 723736.

Thiry, M., Ribet, I., 1999, Groundwater silicifications in Paris Basin limestones: fabrics, mechanisms, and modelling. J. Sedim. Petrol., 69/1, p. 171-183.

Thiry, M., Schmitt, J.-M., Innocent, C., Cojan, I., 2013, Sables et Grès de Fontainebleau : que reste-t-il des faciès sédimentaires initiaux? 14ème Congrès Français de Sédimentologie, 
Paris 2013, Trois excursions géologiques en région parisienne, Livre d'excursions, Publ. ASF, $n^{\circ} 74$, p. 37-90.

Thiry, M., Schmitt, J.-M., Rayot, V., Milnes, A.R., 1995, Géochimie des altérations des profiles blanchis du régolithe tertiaire de l'intérieur de l’Australie. C. R. Acad. Sci. Paris, t. 320, serie II, p. 279-285.

Thiry, M., Simon-Coinçon, R., 1996, Tertiary paleoweatherings and silcretes in the southern Paris Basin. Catena, 26(1), p. 1-26.

Twidale, C.R., Milnes, A.R., 1983, Slope processes active in the scarp retreat cycle. Z. Geomorph., 27, p. 343-361.

White, D.E., Hem, J.D., Waring, G.A., 1963, Chemical composition of subsurface waters. in: . Fleischer, M. (Ed.), Data of Geochemistr., 6th ed., U.S. Geol. Survey Professional

Webb, J.A., Domanski, M., 2008, The relationship between lithology, flaking properties and artefact manufacture for Australian silcretes. Archaeometry, 50, p. 555-575.

Webb, J.A., Golding, S.D.,1998, geochemical mass-balance and oxygen-isotope constraints on silcrete formation and its palaeoclimatic implications in southern Australia. Journal of Sedimentary Research, 68, p. 981-993. Paper 440-F.

Wragg-Sykes R., Chomette D., Defive E., Delvigne V., Lafarge A., Fernandes P., Liabeuf R., Piboule M., Raynal J.-P., 2014, Sondages sur le gite-atelier de Saint-Pierre-Eynac (Haute-Loire) et son environnement géologique. in: J.-P. Raynal, M.-H. Moncel, eds., Programme collectif de recherche Espaces et subsistance au Paléolithique moyen dans le sud du Massif central. Ministère de la Culture et de la Communication , DRAC Auvergne., rapport DRAC 2014-142, vol. 2, p. 1-52.

Wright, M.J., 1983, Red-brown hardpans and associated soils in Australia. Trans R. Soc. S. Aust., 107, p. 252-254. 


\section{Figure captions}

1118 Figure 1 - Rate of dissolution and asymptotic solubility of the different silica varieties at $25^{\circ} \mathrm{C}$ 1119 (after Siffert 1967). Opal and chalcedony show variable solubility according to their 1120 respective crystallinity.

1121 Figure 2 - Quartz and chalcedony solubility versus temperature (computed from geochemist's workbench program; Bethke, 2002). Quartz solubility decreases to more than half of its initial value between 12.5 and $0^{\circ} \mathrm{C}$.

Figure 3 - Solubility of amorphous silica in aqueous salt solutions at $25^{\circ} \mathrm{C}$ (after Marshall, 1980)

Figure 4 - Alumina and silica solubility versus pH (computed from PHREEQC program, U.S. Geological Survey; Parkhurst and Appelo, 1999). Silica is insoluble at acidic and neutral pH that appear favourable for development of silcretes, whereas alumina stability is restricted to neutral $\mathrm{pH}$.

Figure 5 - Eh/pH diagram for Fe-O-H system showing the reaction path leading to ferrolysis after having introduced some oxygen into the $\mathrm{Fe}^{++}$- rich solution. Diagram at $25^{\circ} \mathrm{C}$ in equilibrium with atmospheric $\mathrm{O}_{2}$ and $\mathrm{CO}_{2}$, and [SO4--- $=10^{-7}$ (after Garrels and Christ, 1965).

Figure 8 - Schematic diagram of the Calcaire de Champigny Formation (upper Eocene) showing the distribution and shapes of silicified zones (Plateau of Brie, France). Note similarity between the distribution and shapes of the silicified zones and dissolution features of the limestone. 
1144 Figure 9 - Larkins Folly section exposed in bulldozer costeans in Coober Pedy opal field. The

1145 bleached Cretaceous formations contain termite burrows and alunite nodules. There are

1146 two superposed levels of groundwater silicification. In addition, at the top is a

1147 pedogenic silcrete disrupted by vertical pipe-like structures, and an overlying laminar-

1148 structured red-brown hardpan.

1149 Figure 10 - Sketch of the macromorphological organisation of a pedogenetic quartzose

1150 silcrete and distribution of secondary silica and dissolution structures.

1151 Figure 11 - Thin sections of groundwater silcretes (transmitted light, crossed polars). (A)

1152 Fontainebleau quartzitic silcrete in which original detrital quartz grains are overgrown

1153 by secondary silica, producing triple-point junctions and thus a compact mesh that

1154 results in a rough fracture. (B) Stuart Creek quartzitic silcrete with chalcedonite deposits

1155 in pore spaces produces a lustrous break on knapping.

1156 Figure 12 - Thin sections of silicified limestone (Paris Basin): two views (A) and (B):

1157 transmitted light, crossed polars. The larger crystals are euhedral quartz that crystallized

1158 in voids (v) by precipitation from water, the speckled areas are microcrystalline quartz

1159 ( $\mu \mathrm{Q})$ replacing primary carbonate and the black areas are remnant carbonate $(\mathrm{Ca})$. The

1160 images show the nature of the silicified "front” (dotted line).

1161 Figure 13 - Thin sections of porcellanites (transmitted plane polarised light). (A) Stuart

1162 Creek, South Australia. The dark granular matrix (Op1) is silicified silty claystone.

1163 Voids (v) and channels contain successive silica deposits (Op2), firstly brown opal then

1164 chalcedonite. The latter also impregnates the matrix and results in a compact material

1165 with a lustrous fracture. (B) Sancerre, southern Paris Basin. The dark opal matrix (Op1)

1166 has recrystallized into clear homogeneous microquartz $(\mu \mathrm{Q})$; the opal deposits in the

1167 voids (Op2) remain unaffected. This type of porcellanite provides sharp flakes, like

1168 flints, on knapping.

1169 Fig 14 - Thin sections of pedogenic silcretes, Paris Basin. (A) matrix of amoeboid quartz

1170 microcrystals in net-like arrangement generates a hard and lustrous fracture on knapping

1171 (transmitted light, crossed polars). (B) and (C) nodular facies with illuviation cutans (il)

1172 recrystallized into microquartz plus titania microcrystals; nodules are rimmed by a 
cortex enriched in titania (arrow). Channels remain empty (v) or are cemented with subeuhedral quartz crystals (Q). (Transmitted plane polarised light).

1175 Figure 15 - Schematic view of the Beda pediment showing the distribution of pedogenic

1176 silcrete facies. Facies change completely at a $100 \mathrm{~m}$ scale (after Milnes and Thiry, 1177 1992).

1178 Figure 16 - Schematic morphostratigraphic sketch of landscapes from the Davenport Range,

1179 across the Stuart Range, to the Eucla Basin, South Australia, showing silicification in

1180 relation to different weathering features and their distribution in relation to landsurfaces

1181 and geology (after Simon-Coinçon et al., 1996).

1182 Figure 17 -Schematic section across the Todd River Plain, southeast of Alice Springs, central

1183 Australia, showing the location of different silcrete facies (after Milnes and Thiry, 1184 1992).

1185 Fig. 18 - Schematic geomorphological section across the Paris Basin, showing the 1186 distribution and relationships of silcrete facies. 


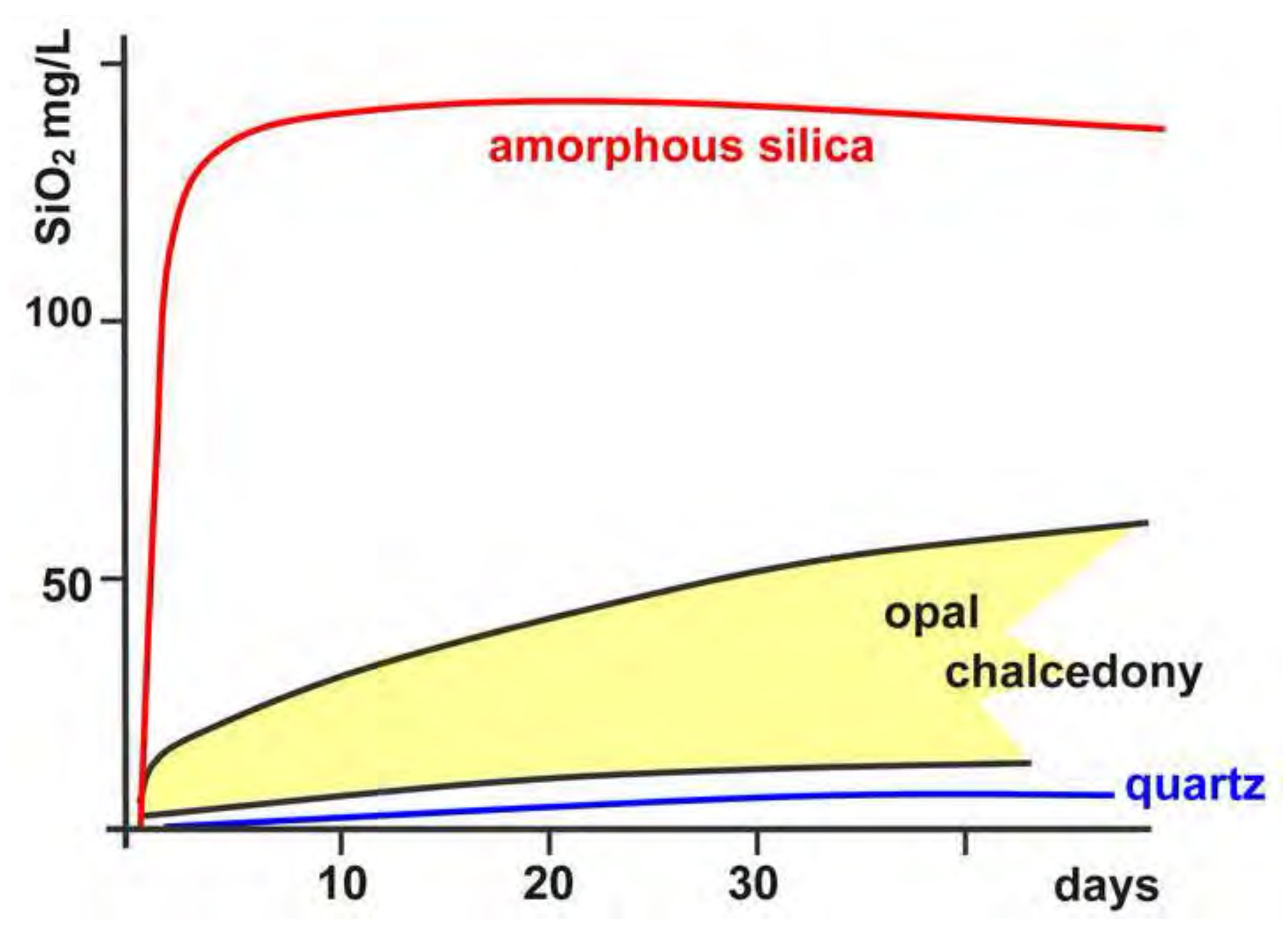


Click here to download high resolution image

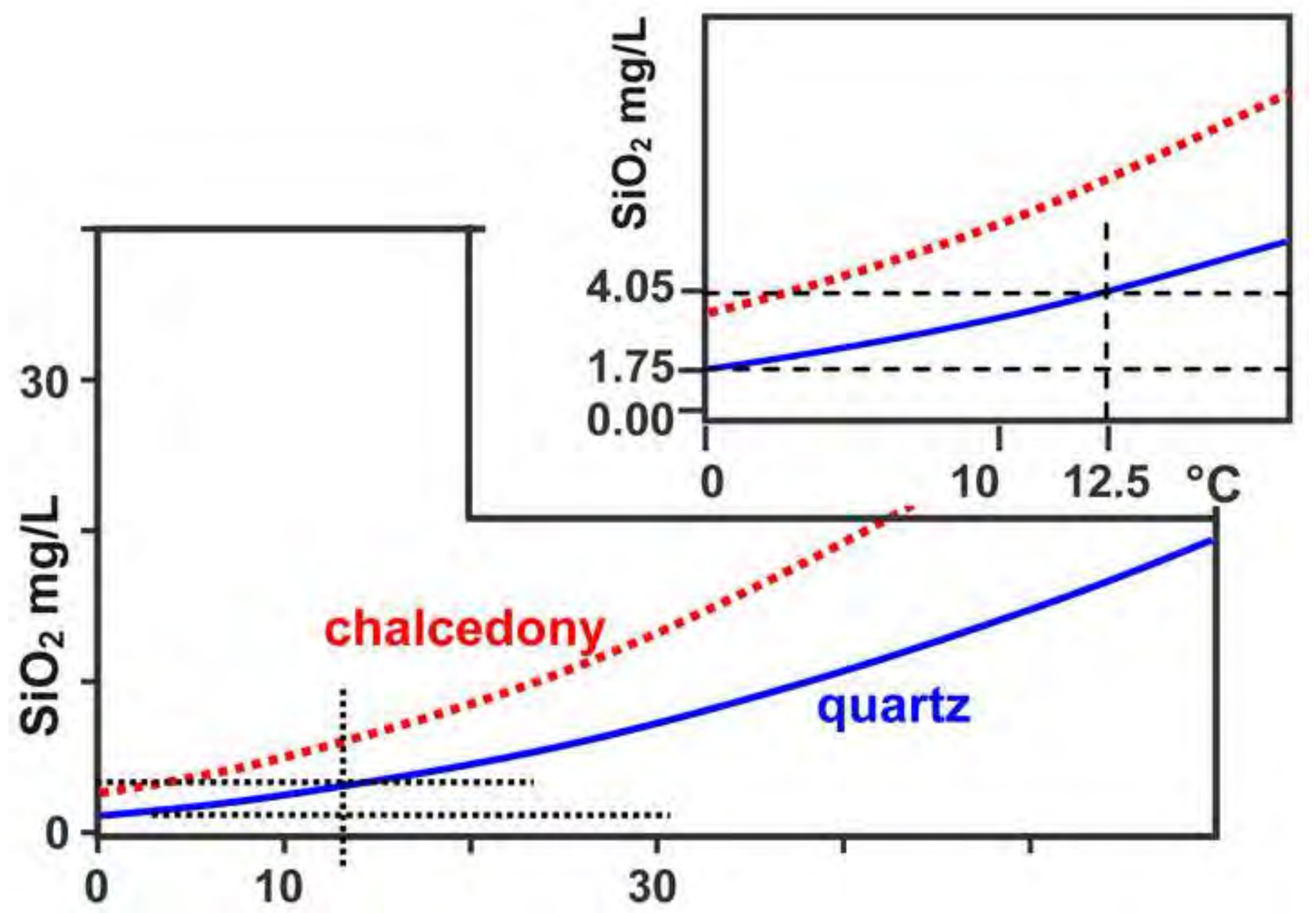

10

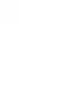


Click here to download high resolution image

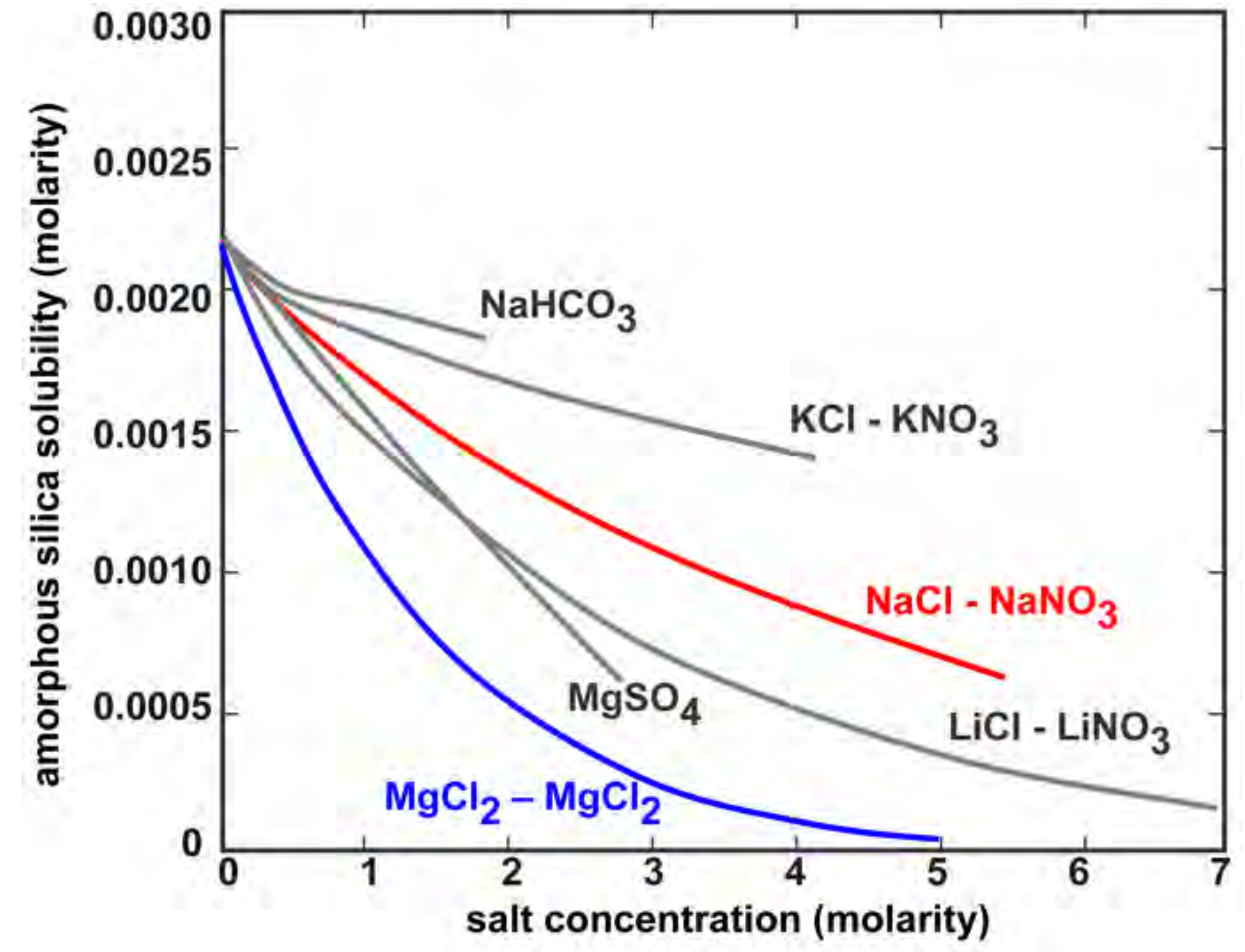




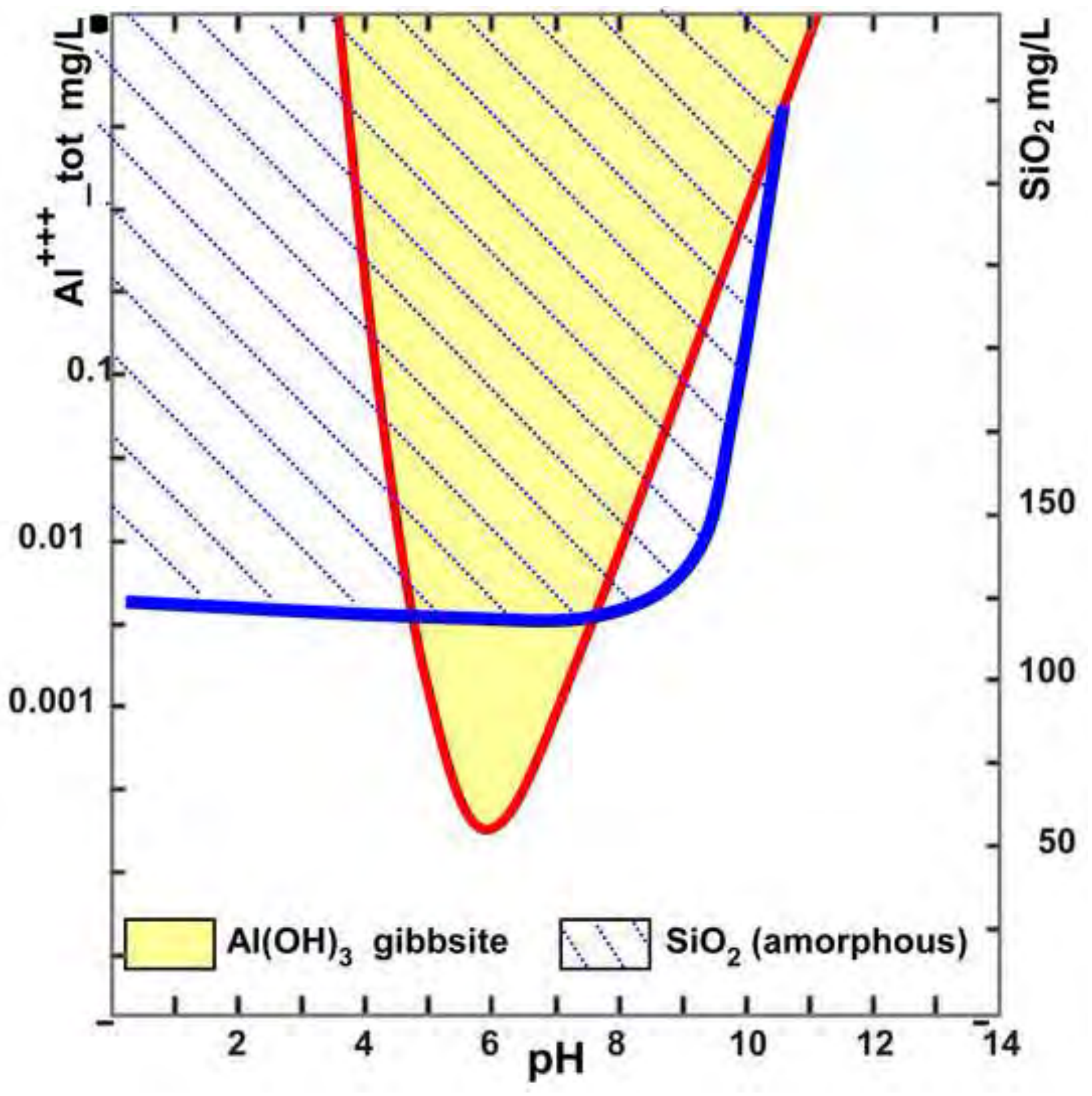


Figure_05_8cm

Click here to download high resolution image

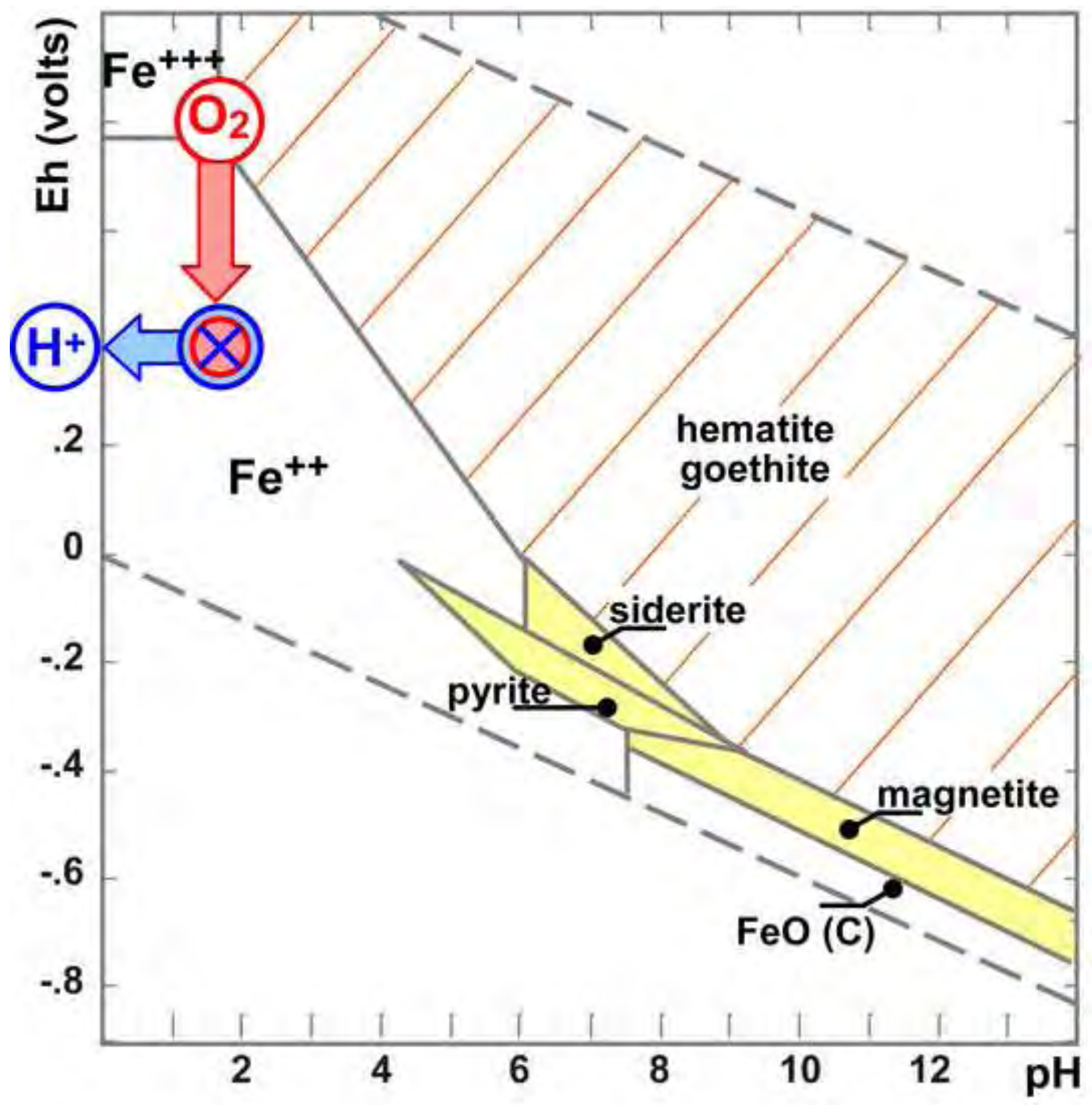




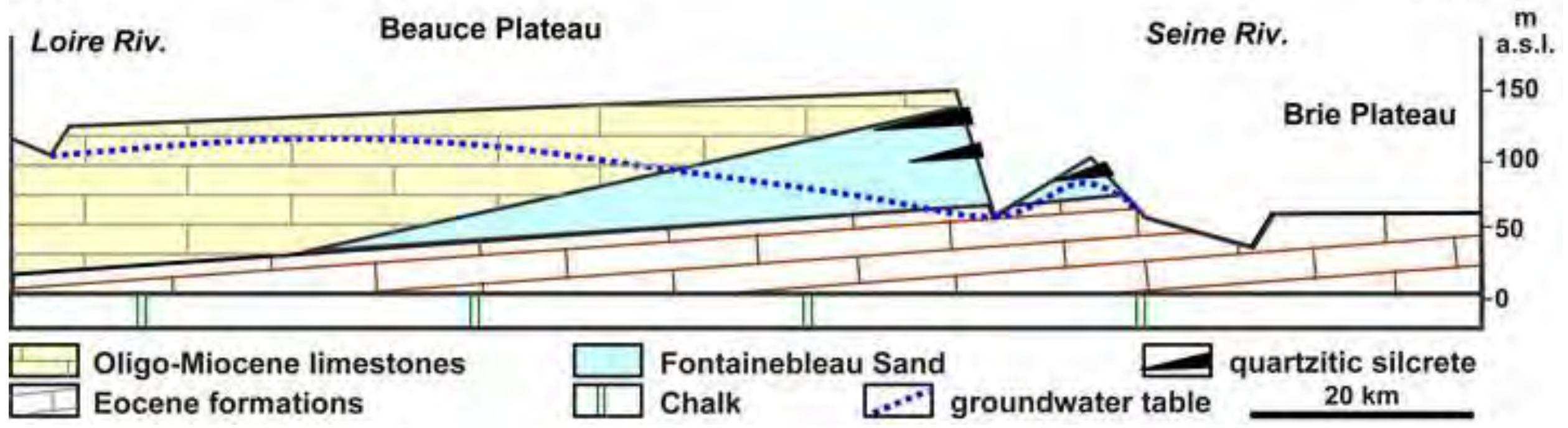


Click here to download high resolution image

\section{STAGE 1}

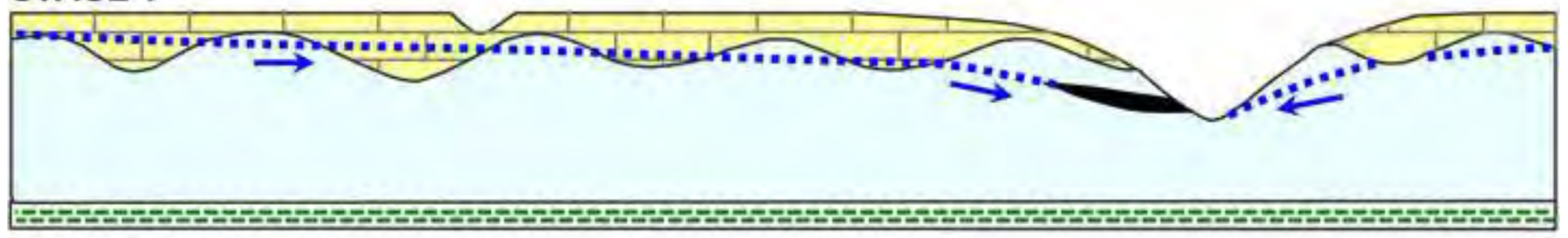

\section{STAGE 2}

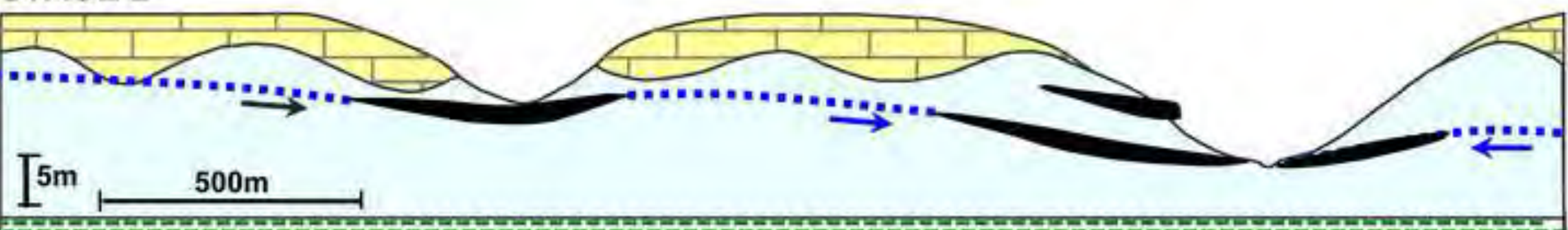

\begin{tabular}{|lll}
\hline$E=E 3$ & $\begin{array}{l}\text { marl } \\
\text { quartzitic silcrete }\end{array}$ & $\begin{array}{l}\text { sand } \\
\text { water table }\end{array}$
\end{tabular}

1 limestone

$\rightarrow \quad$ groundwater flow 


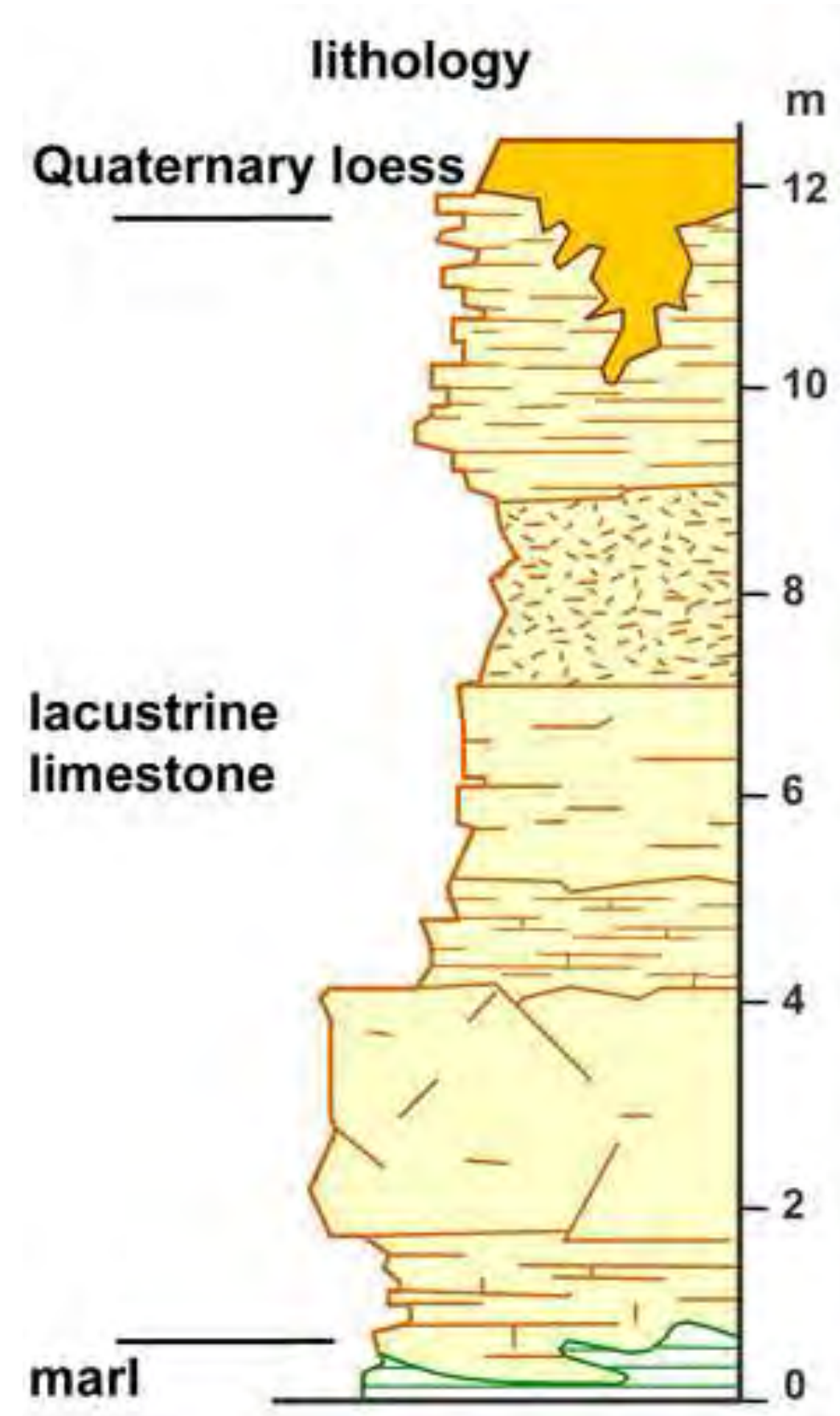

karst features

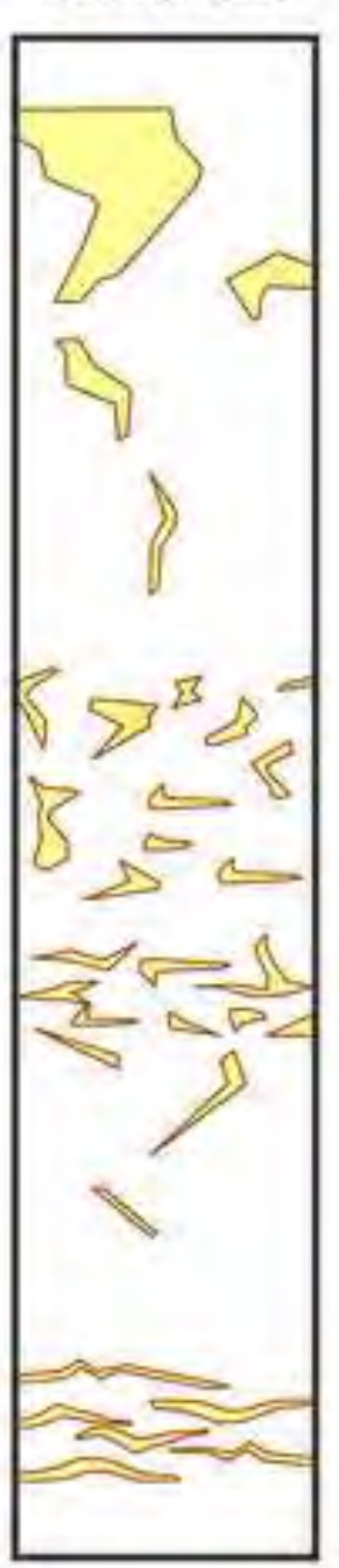

silicified bodies pervasive silicification

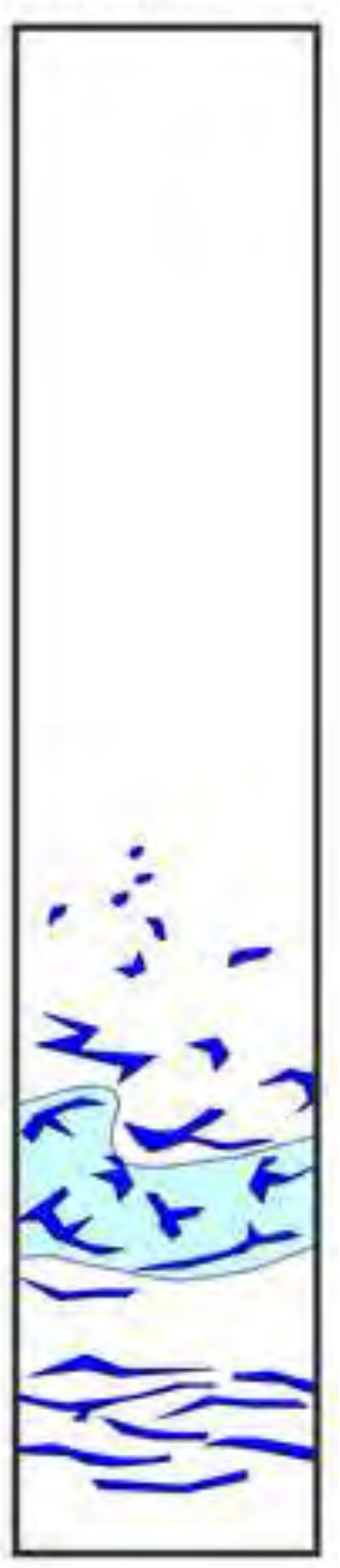

translucent flints 
LITHOLOGY

MINERALOGY

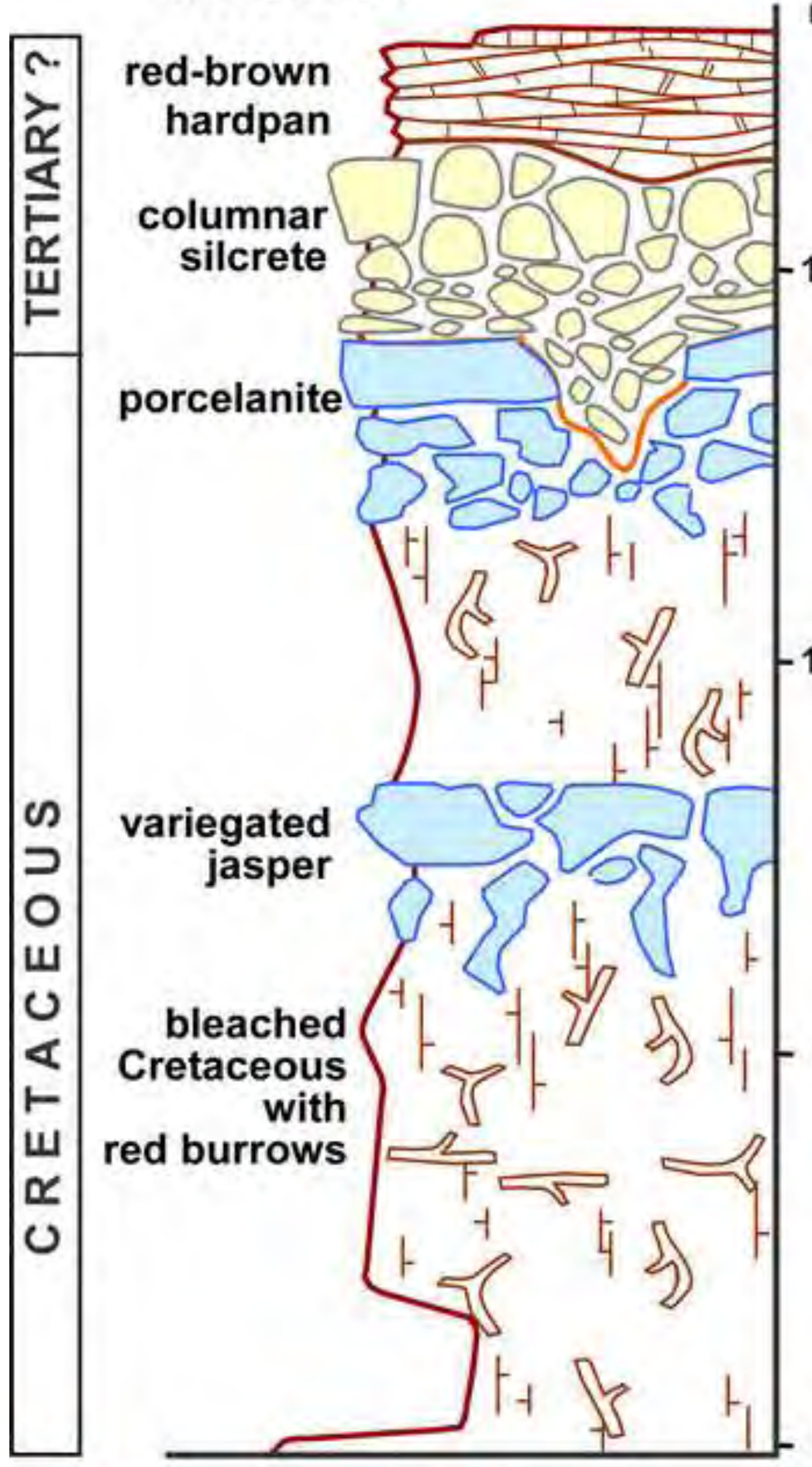

$\mathrm{m}$

10

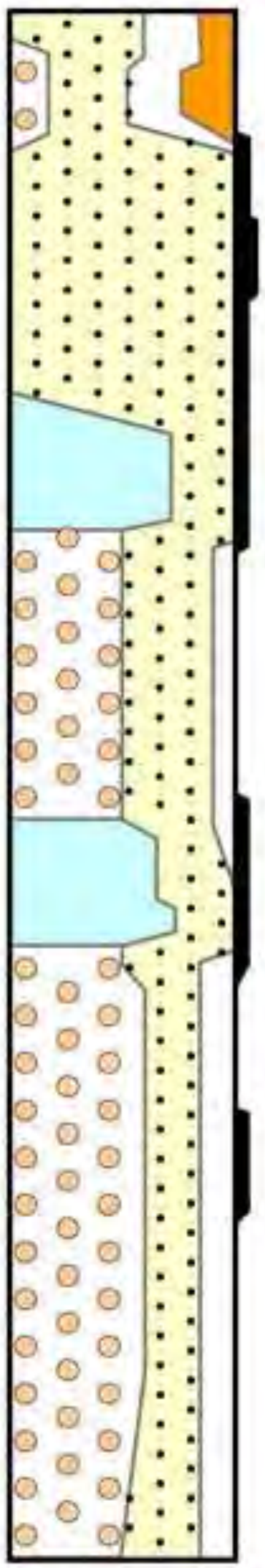

opal-CT

\begin{tabular}{ll}
0 & 9 \\
\hline
\end{tabular}

$\because \cdot$ quartz iron oxides clay minerals anatase 


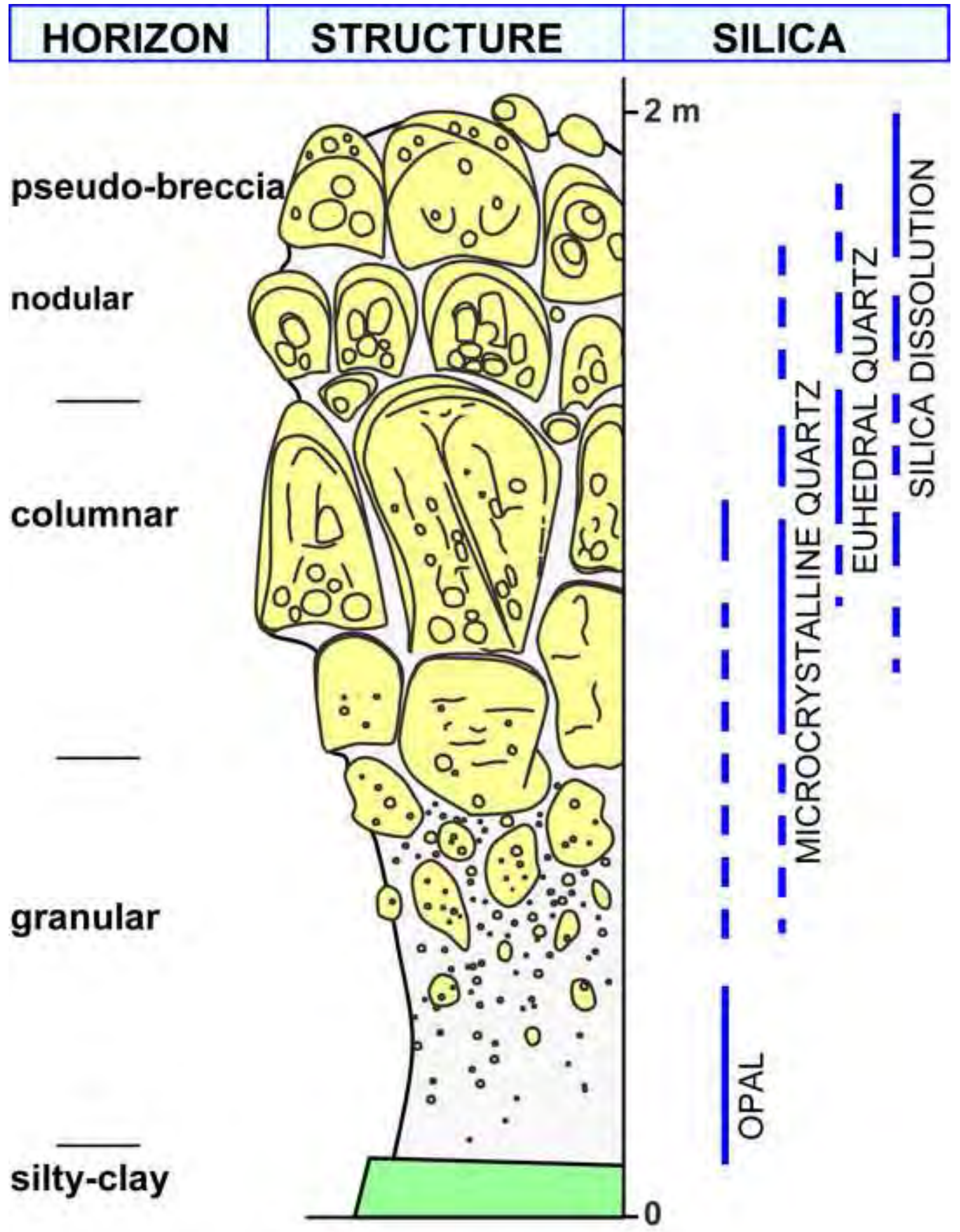


Figure_11_9cm
Click here to download high resolution image
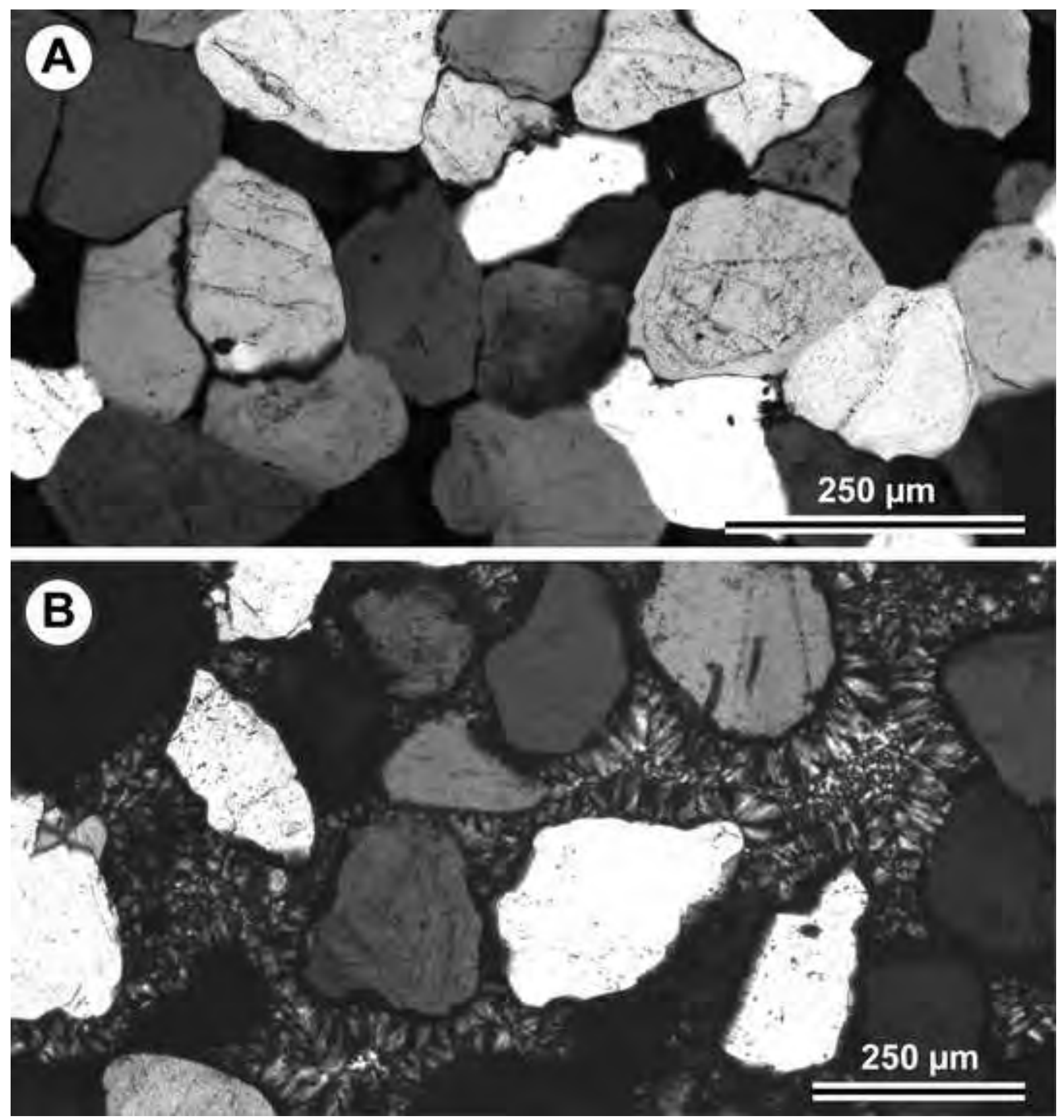


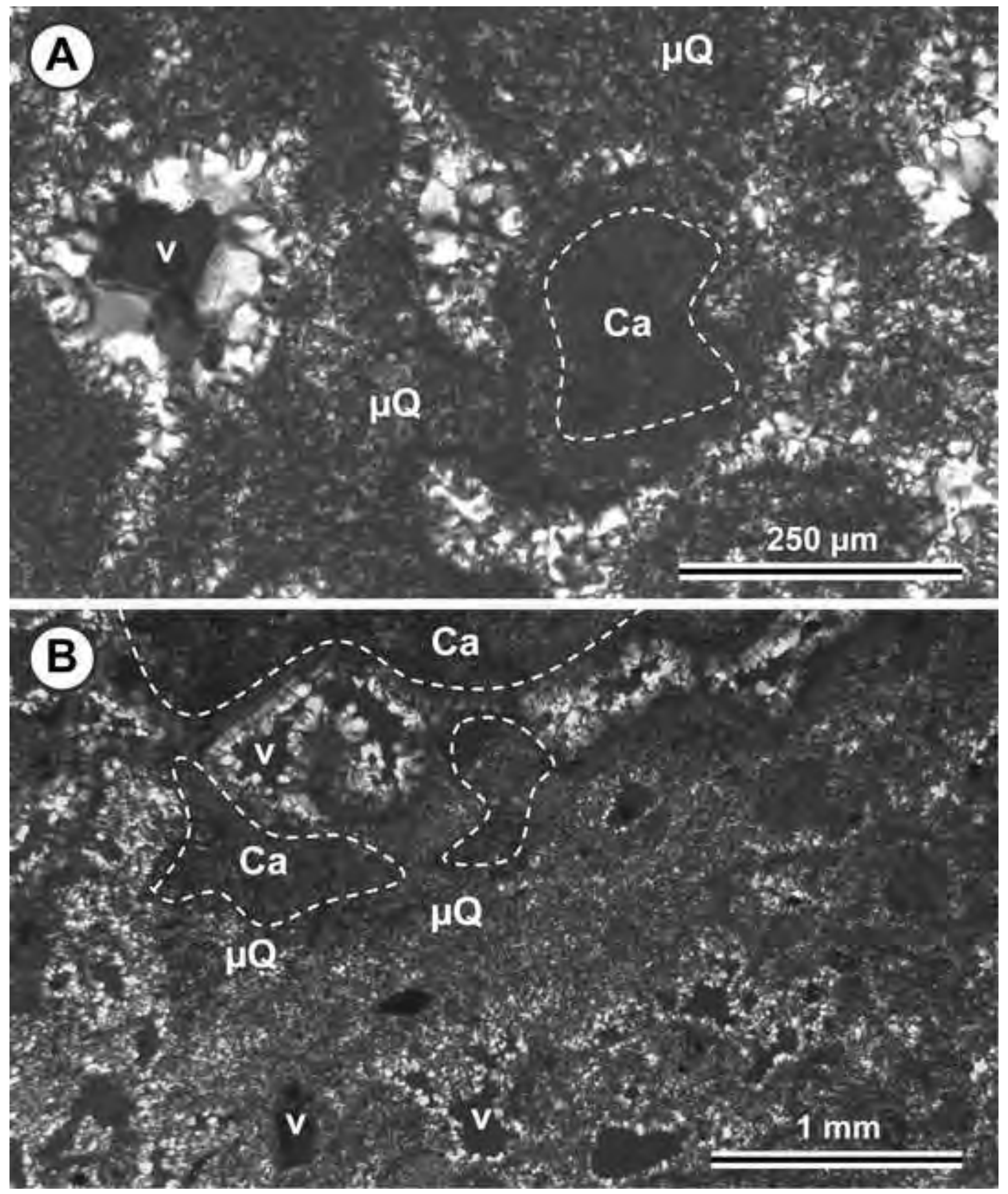



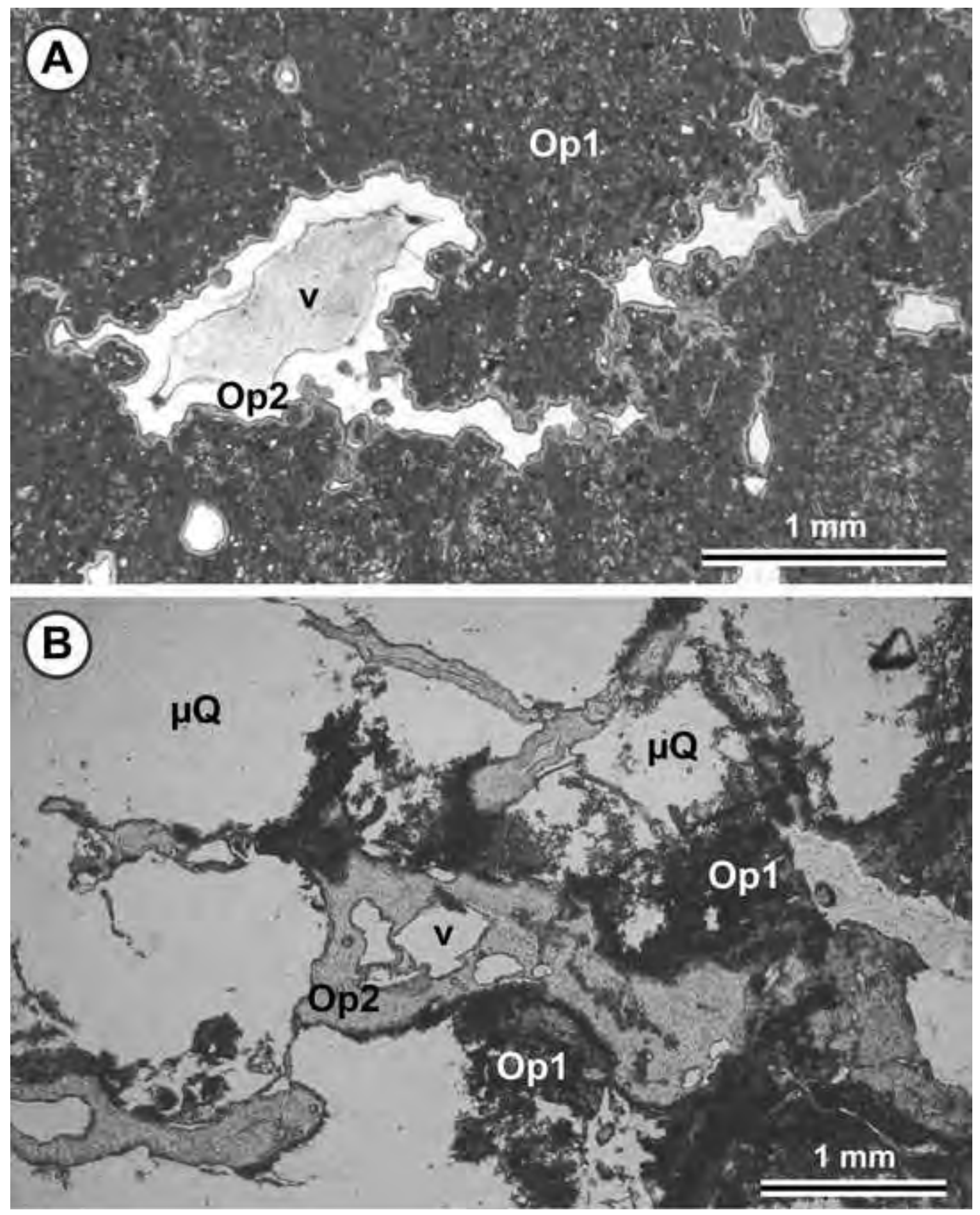

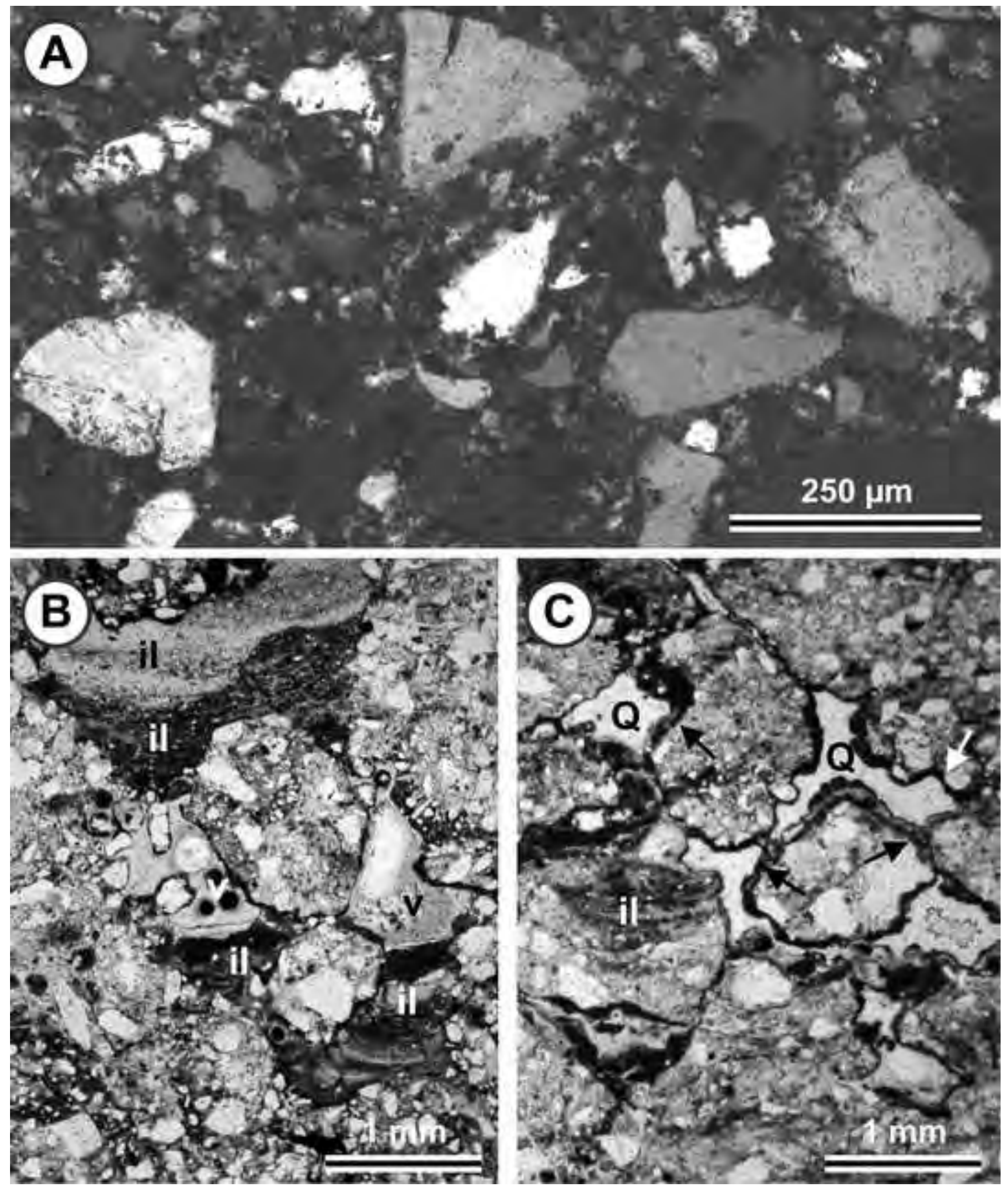
Figure_15_16cm
Click here to download high resolution image

\section{ARCOONA PLATEAU}

LAKE TORRENS PLAIN

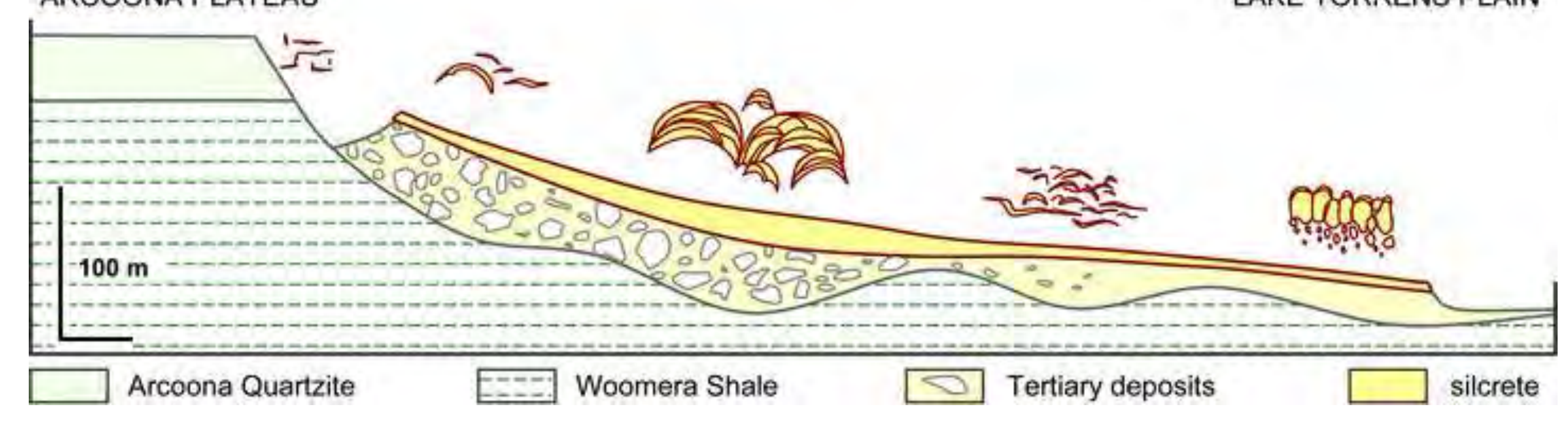


SW

EUCLA BASIN
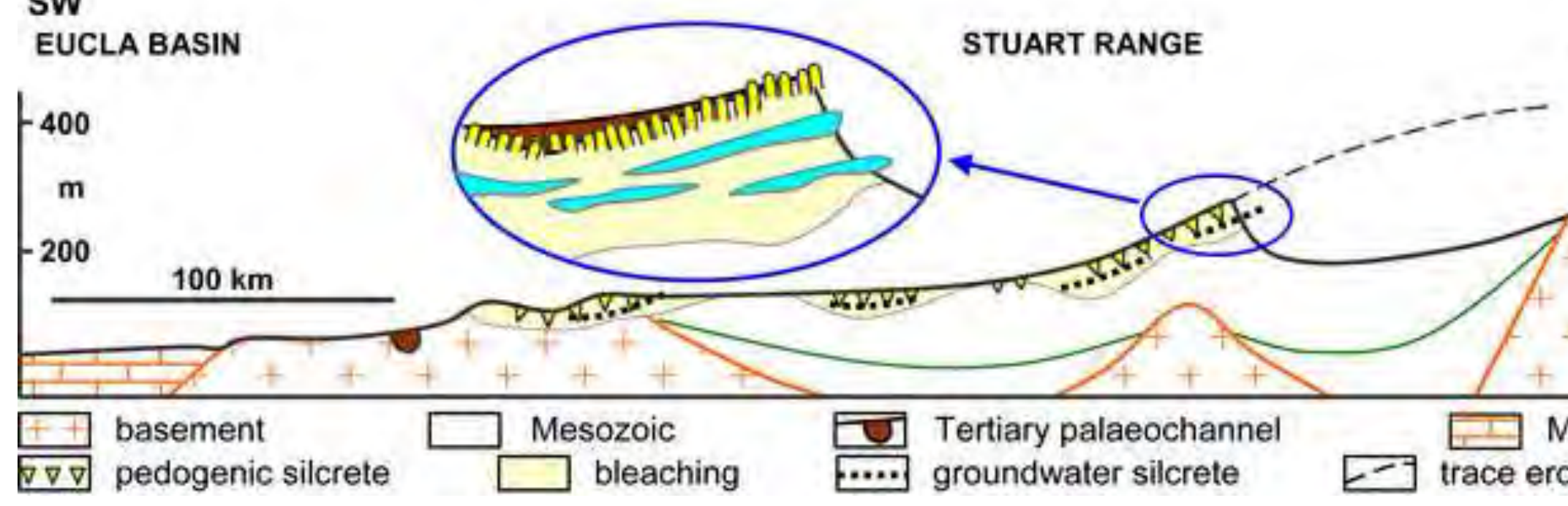

DAVENPORT RANGE

NE

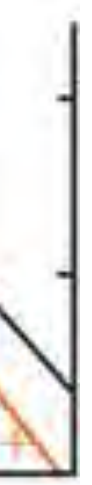

Miocene limestone

groundwater silcrete - - trace eroded paleosurface 
MACDONNELL RANGES

OORAMINNA 


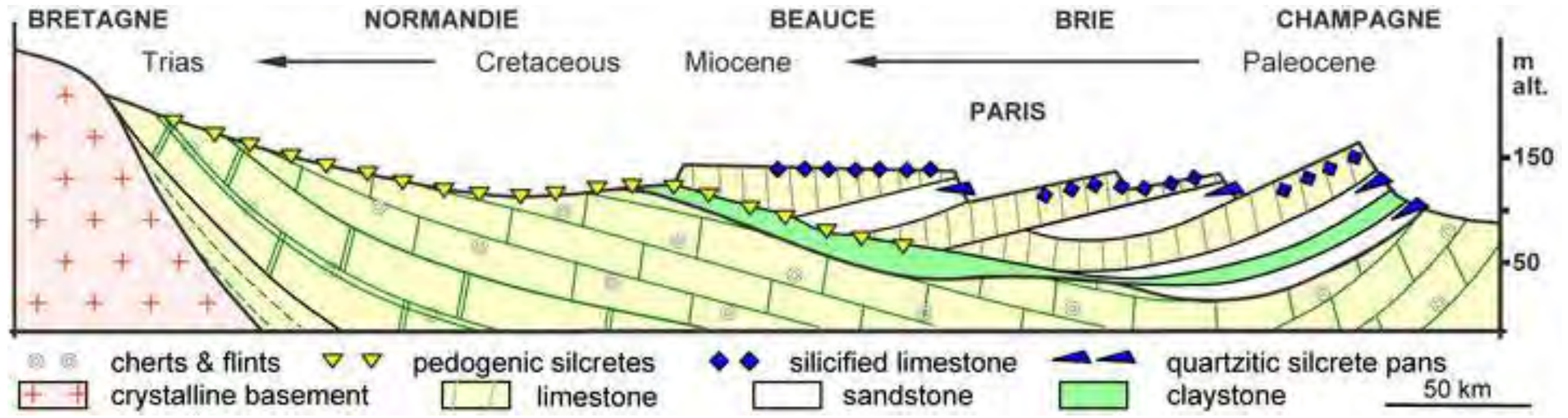

